\title{
Landscape Development Types in Central Lika 1980-2012 - Applying Spatial and Process-Oriented GIS Model
}

\author{
Marta HAMZIĆ1, Borna FUERST-BJELIŠ2 \\ 1 Ericsson Nikola Tesla d.d., Krapinska 45, Zagreb, Croatia \\ marta.jovanic@gmail.com \\ 2 University of Zagreb, Faculty of Science, Department of Geography, Marulićev trg 19, Zagreb, Croatia \\ bornafb@geog.pmf.unizg.hr, ORCID: 0000-0002-6754-4884
}

\begin{abstract}
This paper presents an analysis and definition of development types and subtypes in the landscape of Central Lika, based on processes of change in the period 1980-2012 CORINE Land Cover database data for 1980 and 2012 were used to establish the landscape types in Central Lika in those years. The landscape types in Central Lika were determined according to land cover/land use. Based on the mutual relations between the established landscape types in the two observed years, we established six landscape development types and three subtypes in Central Lika. The spatial distribution of landscape development types and subtypes in Central Lika was determined using the Standard Deviational Ellipse (Directional Distribution) spatial analysis method. The results obtained showed that in the observation period (1980-2012), most of the area of Central Lika (89.46\%) belonged to the Stagnation landscape type. Other development types were present to a much lesser extent (about 5.5\%) and were found to be Vegetation succession, Agrarisation, Vegetation degradation and Built-up land. We established a spatial gradation of three phases in the process of vegetation succession, that is, development subtypes from the centre to the margins of the research area. At the same time, in the observation period, the process and trend of extensification of land use in Central Lika was twice as present as intensification.
\end{abstract}

Keywords: land cover/land use, landscape development types, spatial analysis, process analysis, GIS model, Central Lika

\section{Introduction}

The European landscape today is characterised by a certain polarisation occurring alongside major socioeconomic processes, which in most Western European countries began after the end of the Second World War (Hall and Tewdwr-Jones 2011). The most important initiating forces which affect changes and the shaping of the landscape are accessibility, urbanisation and globalisation (Antrop 2001). Two key trends have been observed - intensification and extensification (Van Eetvelde and Antrop 2009, according to Vos and Klijn 2000), which often lead to

4 consequences in the landscape such as inappropriate sanation, degradation and loss of identity (Andlar et al. 2011, Lončar and Cvitanović 2012) or adoption of a new identity (Hrdalo et al. 2008). So, on the one hand, there are landscapes under the influence of intensification of land use (for example, urban spaces and agricultural estates which are experiencing increased production), while on the other, some are affected by extensification of land use, that is, abandonment (for example, abandoned agricultural estates in distant rural places). In the latter case, due to a reduction in the intensity of socioeconomic activities, the cultural landscape seems to

KiG No. 35, Vol. 20, 2021 https://doi. org/10.32909/kg.20.35.1 - - 


\title{
Razvojni tipovi krajolika srednje Like 1980-2012 - primjena prostorno i procesno orijentiranog GIS-modela
}

\author{
Marta HAMZIĆ1, Borna FUERST-BJELIŠ2 \\ 1 Ericsson Nikola Tesla d.d., Krapinska 45, Zagreb \\ marta.jovanic@gmail.com \\ 2 Sveučilište u Zagrebu, Prirodoslovno-matematički fakultet, Geografski odsjek, Marulićev trg 19, Zagreb \\ bornafb@geog.pmf.unizg.hr, ORCID: 0000-0002-6754-4884
}

\begin{abstract}
Sažetak. U ovom radu provedena je analiza i definicija razvojnih tipova i podtipova krajolika Srednje Like na temelju procesa promjene u razdoblju 1980-2012. Korišteni su podatci baze CORINE Land Cover za 1980. i 2012. godinu, pri čemu su utvrđeni tipovi krajolika Srednje Like za navedene godine. Tipovi krajolika Srednje Like određeni su prema zemljišnom pokrovu i načinu korištenja zemljišta. Na temelju međuodnosa utvrđenih tipova krajolika za dvije promatrane godine, uspostavljeno je šest razvojnih tipova i tri razvojna podtipa krajolika Srednje Like. Prostorna distribucija razvojnih tipova i podtipova krajolika Srednje Like provedena je metodom prostorne analize Elipse standardnih devijacija (Distribucija smjerova) (Standard Deviational Ellipse (Directional Distribution)). Dobiveni rezultati pokazali su da se u promatranom razdoblju najveći dio $(89,46 \%$ ) područja Srednje Like odnosi na razvojni tip krajolika Stagnacija. Ostali ustanovljeni razvojni tipovi zastupljeni su u mnogo manjoj mjeri (ispod 5,5\%), a odnose se na tipove Sukcesije vegetacije, Agrarizacije, Degradacije vegetacije i Izgradnje. Utvrđeno je prostorno stupnjevanje triju faza procesa sukcesije vegetacije, odnosno razvojnih podtipova od središnjeg prema rubnom području istraživanja. Također, u promatranom razdoblju proces i trend ekstenzifikacije korištenja zemljišta Srednje Like dvostruko je zastupljeniji od intenzifikacije.
\end{abstract}

Ključne riječi: zemljišni pokrov i način korištenja zemljišta, razvojni tipovi krajolika, prostorna analiza, procesna analiza, GIS-model, Srednja Lika

\section{Uvod}

Današnje europske krajolike obilježava svojevrsna polariziranost koja se pojavila usporedno s glavnim društveno-gospodarskim procesima koja se $\mathrm{u}$ većini zapadnoeuropskih zemalja počeli događati po završetku Drugog svjetskog rata (Hall i Tewdwr-Jones 2011). Pri tome najvažnije pokretačke sile koje utječu na promjene i oblikovanje krajolika su: dostupnost, urbanizacija i globalizacija (Antrop 2005). Opažaju se dva ključna trenda - intenzifikacija i ekstenzifikacija (Van Eetvelde i Antrop 2009 prema Vosu i Klijnu 2000), koji u krajoliku često imaju za posljedicu neprikladnu sanaciju, degradaciju i gubljenje identiteta (Andlar i dr. 2011, Lončar i Cvitanović 2012), odnosno dobivanje novog identiteta (Hrdalo i dr. 2008). Tako s jedne strane, postoje krajolici koji su pod utjecajem intenzifikacije korištenja zemljišta (npr. urbani prostori, poljoprivredni posjedi koji doživljavaju povećanje proizvodnje), a s druge strane, oni koji su pogođeni ekstenzifikacijom korištenja zemljišta, odnosno njegovim zapuštanjem (npr. zapušteni poljoprivredni posjedi udaljenih ruralnih prostora). U potonjima će, zbog smanjivanja intenziteta društveno-gospodarskih aktivnosti, kulturni krajolik naizgled poprimati 
take on an appearance more like the natural landscape, although it remains the cultural landscape.

The landscape continues to change over time, according to the actions and interactions of numerous variables in the inanimate, animate and social environments, and this makes modelling the features of the landscape within GIS extremely demanding (Water 2002). However, GIS provides much greater opportunities for inventarising and analysing individual parts of the landscape, whose complexity requires diverse data from a range of different sources, and analytical techniques and modelling which cannot be applied in conventional maps (Goodschild 1993, Vogiatzakis 2003).

In this research, based on spatial data on land cover/land use in two comparison years (1980 and 2012), the landscape types of Central Lika were established and shown cartographically. Based on their mutual relations (according to the conceptual models illustrated in the paper), landscape development types in Central Lika were established and depicted cartographically for the observation period 1980-2012. Based on the interrelation of the established landscape types for the period in question, three subtypes were identified within one landscape type (Vegetation succession). For the analysis of landscape development in Central Lika, a spatial and process-oriented GIS landscape development model was applied.

Two databases provided the data for this research - CORINE Land Cover for 1980 and 2012 (CLC 1980 and CLC 2012). ${ }^{1}$ These data allow an insight into the natural and anthropogenic elements which are visible in a space, and which can be shown and analysed through the concept and category of land cover/ land use.

The CLC 1980 and CLC 2012 databases consist of digital spatial data which relate to parts of the landscape (for example, settlements, pastureland, lakes, etc.) and are arranged in data classes. For the purposes of this research, all the data classes relating to the area of Central Lika for each observed year were arranged in one of the landscape types. Thus, for example, the data classes Pastureland and Natural Grassland for 1980 were placed in the landscape type

\footnotetext{
${ }^{1}$ The research was conducted over several years and completed before the CORINE Land Cover data for 2018 were available. The data were supplemented and corrected through field research. Since landscape changes are subject to a much longer time scale than a few years, a difference of only a few years does not essentially affect the results obtained.
}

Grassland. At the same time, we tried to arrange the data classes for the observed years in individual landscape types, so that they would be as mutually homogeneous as possible, given their natural-geographic features and the socioeconomic landscape development factors visible in the space. The analysis of the spatial arrangement of development subtypes was performed using the Standard Deviational Ellipse (Directional Distribution) spatial analysis method.

The aim of the research, through the use of GIS models, was to establish the landscape types in Central Lika in 1980 and 2012, and based on their mutual relations, to establish and depict cartographically the landscape development types in Central Lika and their spatial distribution and surface proportions for the observed period. The data derived from field research were supplemental and corrective, in addition to the accessibility of published data. ${ }^{2}$

\subsection{Overview of previous research}

For the purpose of researching the landscape, its development and changes over time in the literature, various types of data were used, based on different approaches and processing methods. Thus, the time-span of the research depends to a great extent on the accessibility and availability of the corresponding types of sub-data and information.

Studying landscape development over a long period (for example, more than 250 years) is made possible by combining the use of limited and specific kinds of historical and modern graphic and narrative information, along with complex approaches and methods. In Croatia, for example, the key periods in development and changes to the environment through various anthropogenic influences, in a study of Velebit from the $17^{\text {th }}$ century to the present day, were defined by Fuerst-Bjeliš, Lozić and Perica (2000). Another study of environmental changes in the central part of Dalmatian Zagora was carried out by Fuerst-Bjeliš (2003), who established the key processes in environmental changes over a period of 250 years through a comparative analysis of textual, graphic and numerical data from the $18^{\text {th }}$-century Viennese cadastre and modern topographic maps. Somewhat later, narrative details noted in the travelogues of $18^{\text {th }}$ - and $19^{\text {th }}$-century natural historians were added to the analysis along

\footnotetext{
2 See note 1.
}

KiG No. 35, Vol. 20, 2021, https://doi.org/10.32909/kg.20.35.1 - 
oblik sličan prirodnom krajoliku, no on i dalje ostaje kulturni krajolik.

Krajolik se kontinuirano mijenja tijekom vremena, što uključuje akciju i interakciju brojnih varijabli iz neživog, živog i društvenog okruženja, što modeliranje obilježja krajolika u okviru GIS-a čini vrlo zahtjevnim (Waters 2002). Međutim, upravo GIS pruža znatno veće mogućnosti za inventarizacije i analize pojedinih dijelova krajolika, čija složenost zahtijeva raznolikost podataka iz niza različitih izvora, te analitičke tehnike i modeliranja koji se ne mogu primijeniti na konvencionalne karte (Goodchild 1993, Vogiatzakis 2003).

U radu su na temelju prostornih podatka o zemljišnom pokrovu i načinu korištenja zemljišta za dvije usporedne godine (1980. i 2012.) utvrđeni i kartografski prikazani tipovi krajolika Srednje Like. $\mathrm{Na}$ temelju njihova međuodnosa (prema konceptualnim modelima koji su grafički prikazani u radu) uspostavljeni su i kartografski prikazani razvojni tipovi krajolika Srednje Like za promatrano razdoblje 1980-2012. Na temelju međuodnosa utvrđenih tipova krajolika, unutar jednog tipa krajolika (tip krajolika Sukcesija vegetacije) uspostavljena su i tri razvojna podtipa. Pri analizi razvoja krajolika Srednje Like primijenjen je prostorno i procesno orijentirani GISmodel razvoja krajolika.

U radu su korišteni podatci iz dviju baza podataka - CORINE Land Cover iz 1980. i 2012. godine (CLC 1980 i CLC 2012). ${ }^{1}$ Ti podatci daju uvid u prirodne i antropogene elemente koji su vidljivi u prostoru, a mogu se prikazati i analizirati kroz koncept i kategorije zemljišnog pokrova i načina korištenja zemljišta.

Baze podataka CLC 1980 i CLC 2012 sastoje se od digitalnih prostornih podataka koji se zapravo odnose na dijelove krajolika (npr. naselje, pašnjak, jezero i sl.), a raspoređeni su u klase podataka. Za potrebe ovog rada sve su klase podataka koje se odnose na područje Srednje Like za svaku pojedinu promatranu godinu raspoređene $u$ jedan od tipova krajolika. Tako su primjerice klase podataka Pašnjaci i Prirodni travnjaci za 1980. godinu svrstane u tip krajolika Travnato zemljište. Pri tome se klase podataka

\footnotetext{
${ }^{1}$ Istraživanje je provođeno kroz nekoliko godina i završeno prije nego što su podatci CORINE Land Cover za 2018. godinu bili dostupni. Podatci su dopunjeni i korigirani terenskim istraživanjem. S obzirom na to i da promjene krajolika podliježu mnogo duljoj vremenskoj skali nego što je to nekoliko godina, razlika od nekoliko godina ne može suštinski utjecati na dobivene rezultate.
}

promatranih godina težilo rasporediti u pojedini tip krajolika tako da međusobno budu što homogeniji s obzirom na njihova prirodno-geografska obilježja i društveno-geografske čimbenike razvoja krajolika koji su vidljivi u prostoru. Analiza prostornog razmještaja razvojnih podtipova provedena je korištenjem metode prostorne analize Elipse standardnih devijacija (Distribucija smjerova) (Standard Deviational Ellipse (Directional Distribution)).

Cilj je istraživanja, primjenom GIS-modela, utvrditi tipove krajolika Srednje Like za 1980. i 2012. godinu, a temeljem njihova međuodnosa uspostaviti i kartografski prikazati razvojne tipove krajolika Srednje Like i njihovu prostornu distribuciju i površinske udjele za promatrano razdoblje. Podatci dobiveni terenskim istraživanjem imali su pri tome dopunski i korektivni karakter, nastavno na dostupnost objavljenih podataka. ${ }^{2}$

\subsection{Pregled dosadašnjih istraživanja}

U svrhu istraživanja krajolika, njegovog razvoja i promjena kroz vrijeme $\mathrm{u}$ literaturi se koriste različite vrste podataka na kojima se temelje različiti pristupi i metode njihove obrade. Pri tome vremenski raspon istraživanja uvelike ovisi o dostupnosti i raspoloživosti odgovarajućih vrsta podataka i informacija.

Proučavanje razvoja krajolika kroz dugi vremenski raspon (npr. duži od 250 godina) moguće je kombiniranim upotrebom ograničenih i specifičnih vrsta povijesnih i suvremenih grafičkih i narativnih podataka, te složenih pristupa i metoda. U Hrvatskoj, primjerice, u radu Fuerst-Bjeliš, Lozić i Perice (2000) definirani su ključni periodi u razvoju i promjeni okoliša na studiji slučaju Velebita kroz različiti antropogeni utjecaj od 17. stoljeća do danas. Na drugoj studiji promjena okoliša za područje središnjeg dijela Dalmatinske zagore Fuerst-Bjeliš (2003) je, komparativnom analizom tekstualnih, grafičkih i numeričkih podataka mletačkog katastra iz 18. stoljeća i suvremenih topografskih karata utvrdila ključne procese promjena okoliša kroz 250 godina. Nešto kasnije, $u$ analizu su dodatno uvedeni, uz ortofotokarte i narativni podatci zabilježeni u putopisnim studijama prirodoslovaca 18. i 19. stoljeća (Fuerst-Bjeliš i dr. 2011). Blaće je analizirao promjene korištenja zemljišta Ravnih kotara od početka 18. stoljeća do danas (2015) te promjenu šumskog pokrova od 19. stoljeća (2019). Koristio je kartografske prikaze,

\footnotetext{
2 Vidi 1.
} 
with orthophotos (Fuerst-Bjeliš et al. 2011). Blaće analysed changes in land use in Ravni Kotari from the early 18th century to the present day (2015) and changes in the forest cover from the $19^{\text {th }}$ century onwards (2019). He used cartographic depictions, the Viennese and Francis Land Cadastres, and information from later revisions, while applying spatial-analytical GIS tools and a statistical-spatial analysis. Durbešić (2012) and Durbešić and Fuerst-Bjeliš (2016) researched landscape changes (mostly to the vegetation cover) from the $19^{\text {th }}$ century onwards, in a study of the south slopes of Svilaja. They used various types of data: the Austrian cadastre on land cover/land use, the CORINE Land Cover database, topographic and forestry maps, satellite images, and field research data for the most recent period. They defined landscape types for three comparative periods from the $19^{\text {th }}$ century to the present day, along with trends which correspond conceptually to landscape development types in this paper.

In Slovenia, there is a strong tradition of researching changes in land use based on data from the Franciscan cadastre for historical periods. In the context of landscape development over a long timespan, the research by Geršič, Gabrovec and Zwitter (2018) stands out, in which landscape changes in the area of Hraški Listneki were analysed from the first half of the 19th century to the present day. The research used data from the Joseph and Francis Land Cadastres for comparative purposes, along with data from the 2013 land cadastre and evidence of actual use of agricultural and forest lands from 2018, digital orthophoto information, and field research data. The research by Gabrovec and Kumer (2019) should also be highlighted, also based on the Francis Land Cadastre and land use database for 2016, which defined types of land use changes and indices of change for the area of Slovenia since the $19^{\text {th }}$ century.

Studying landscape development in the more recent period and over a shorter time-span has allowed the use of newer, more numerous types of data, approaches and methods. Esbah (2009) researched landscape development by analysing changes to the structural features of landscape samples in the urban area of Aydin in Turkey, in two observation years (1977 and 2002). She used a large number of indicators, that is spatial analysis methods, but without establishing developmental types and/or trends. Lončar and Cvitanović (2012) also used various types of data and analysed changes to the environment in the river Drava lowlands in Osijek region, in connection with socioeconomic and demographic factors in the second half of the 20th century, again without determining development types and/or trends of change. In studies by Cvitanović $(2014,2014 a)$ and Cvitanović and FuerstBjeliš (2018), research was conducted into landscape development in Hrvatsko zagorje region from 1978 to 2011 and from 1991 to 2011 respectively, based on a combined methodological approach which included quantitative and qualitative data and analyses (descriptive-analytical, spatial-statistic (GIS), inferential-statistic and empirical research methods). Morić-Španić and Fuerst-Bjeliš (2017), using a combination of various data from two comparative years, a 1975 vegetation map and CORINE Land Cover, Croatian Forestry data and digital orthophoto images (2011), defined landscape types and trends of change, which also corresponded conceptually to the development types in this study. In more recent research into changes in the vegetation cover in continental Croatia, remote research methods and a simulation analysis model and projections of change have been introduced (Jogun et al. 2017, Jogun et al. 2019).

Apart from these works, in which landscape development over long or short periods has been studied, other individual works have determined landscape types for one particular observed point in time in relation to the data used. For the area of Dubrovačko Primorje, Hrdalo et al. (2008) classified landscape types according to purpose and natural spatial features, and identified three basic groups of cultural landscapes: fields, drywalls as an element in fencing, and terraces. Mücher et al. (2010) used four types of data (climate features, height above sealevel, soil composition and vegetation cover/land use), each of which was displayed in one reference point, and identified four hierarchical levels of landscape classification at the level of Europe. The first level relates to climate features, the second to height above sea-level, the third to soil composition, and the fourth to the vegetation cover/land use.

The application of the GIS model when researching various (parts of) landscapes, that is phenomena in the landscape, as is evident, is based on various types of data and data sources. The situation at one point in time or development between two or three points in time, or time periods, is analysed. A minor part of researching landscape changes, however, is that which determines landscape development types and/or trends alongside changes. In this study, apart from defining landscape development types which correspond to observed development

KiG No. 35, Vol. 20, 2021, https://doi.org/10.32909/kg.20.35.1 ـ ـ 


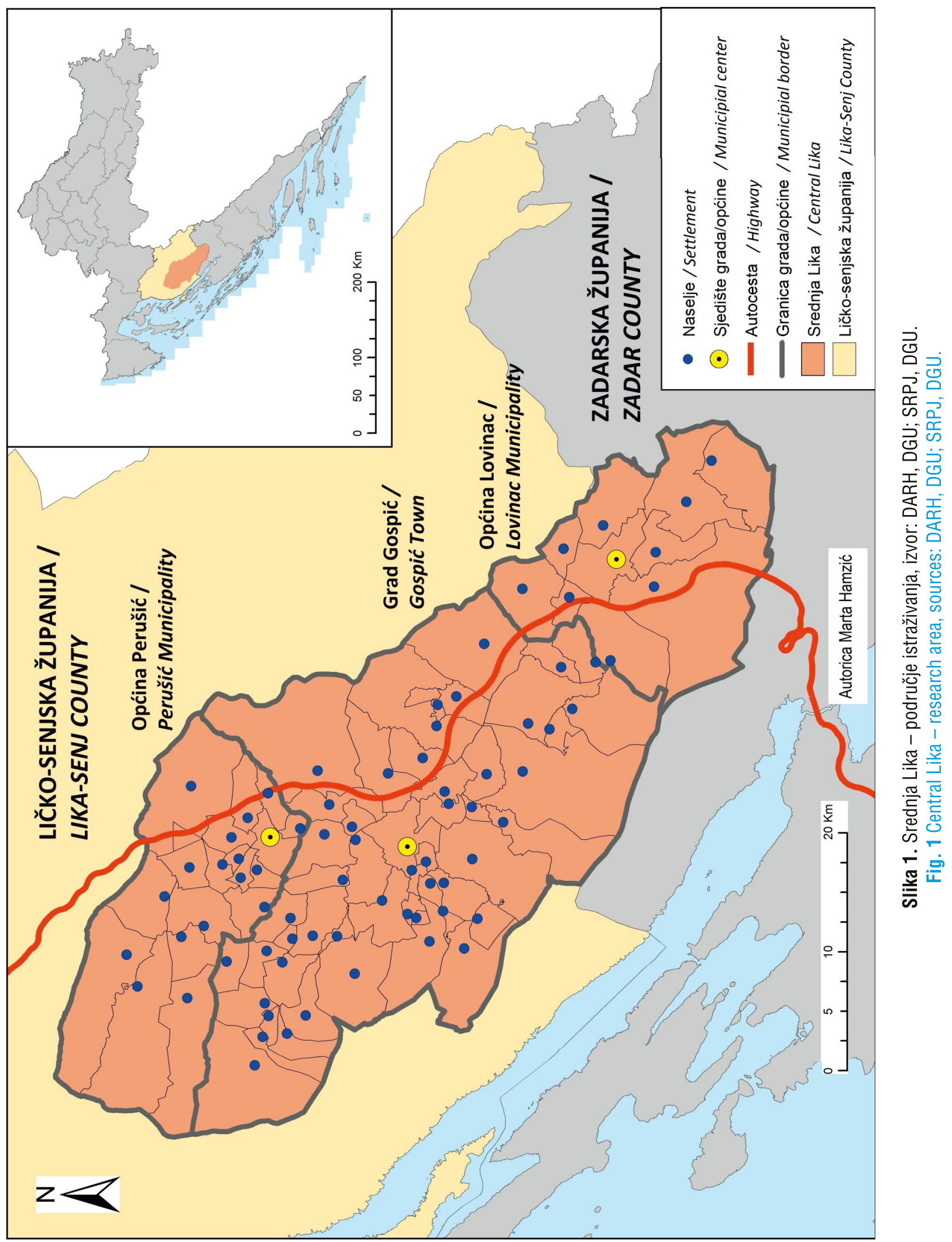


trends, the Standard Deviational Ellipse (Directional Distribution) spatial analysis method was used to determine the spatial distribution of landscape development subtypes.

\subsection{Area of research}

The area of research was Central Lika in Croatia, which according to current administrative-territorial organisation is covered by three units of local self-government: the town of Gospić, the municipality of Lovinac, and the municipality of Perušić. It forms part of Lika-Senj County.

The total surface area of the research area is approximately $1,690 \mathrm{~km}^{2}$. The town of Gospić occupies $967 \mathrm{~km}^{2}$, while the municipality of Perušić $\left(381 \mathrm{~km}^{2}\right)$ and the municipality of Lovinac $\left(342 \mathrm{~km}^{2}\right)$ are smaller. There are 78 settlements in the research area, of which 50 belong to the administrative area of the town of Gospić, 18 to the municipality of Perušić, and 10 to the municipality of Lovinac (Figure 1).

Since the end of the Second World War, Central Lika has been significantly affected by depopulation and the ageing of the population, deagrarisation, deruralisation, and urbanisation. Depopulation and lifestyles changes have inevitably been directly reflected in land use and landscape changes, in which extensification processes dominate.

\section{Methodological Notes}

The GIS landscape development model of Central Lika consists of spatial data which are found in the landscape development spatial database and spatial analyses for detecting processes in the landscape (Figure 2). Some methodological notes on the use of data and spatial analysis methods follow.

\subsection{Methodological notes on the use of data in the GIS landscape development model of Central Lika}

The GIS landscape development model of Central Lika was produced using two databases: CORINE Land Cover 1980 (CLC 1980) and CORINE Land Cover 2012 (CLC 2012). At the European level, these databases were produced as part of the Copernicus Land Monitoring Service project, and the parts of them which refer to the Republic of Croatia were produced by the Croatian Agency for the Environment and Nature (HAOP). These databases follow the standard approach for CLC databases, which is based on the visual interpretation of satellite images according to accepted CLC methodology. Data are produced in a vector data model in the scale 1:100 000, the minimum width of the polygon for linear entities (lines) is $100 \mathrm{~m}$ and 25 ha for surface entities (polygons). It is also extremely important to emphasise that not all elements are entered in the database. For example, in the landscape type Built-up land, smaller settlements are not shown, because they do not meet the criterion of sufficient concentration of objects in relation to the resolution of the grid. Also, in this landscape type, only highways are visible, as smaller roads are not wide enough in relation to the grid. With the aim of establishing the Central Lika landscape types and landscape development types as accurately as possible, data from the databases were used as factual and analysed as such in this work.

In the area of Central Lika, according to the approach outlines in the introduction, 17 data classes were found in the CLC 1980 database, arranged in seven landscape types, while in the CLC 2012 database, 19 data classes were arranged in six landscape types. ${ }^{3}$ It seems that not all the data classes established in 2012 were included in 1980. On the other hand, one landscape type established in 1980 (Rocky surfaces) was missing in 2102.

The Central Lika landscape development types for the study period 1980 to 2012 were determined pursuant to a comparison of landscape types for each individual year, according to a conceptual model of landscape development types (Figure 3). Six landscape development types were defined: Builtup land, Agrarisation, Vegetation succession, Vegetation degradation, Stagnation, and Water areas. In addition, within the development type Vegetation succession,

\footnotetext{
${ }^{3}$ After conducting the procedure, for 1980 the landscape type Built-up land contained three data classes: Discontinuous urban fabric; Industrial or commercial units, and Mineral extraction sites. For 2012, the same landscape type had two additional data classes: Road and rail networks and associated land, and Construction sites. The landscape type Grassland had two data classes in 1980 and 2012; Pastures and Natural grassland. The landscape type Agricultural land had three data classes for 1980 and 2012: Non-irrigated arable land; Heterogeneous agricultural areas, and Land principally occupied by agriculture, with significant areas of natural vegetation. The landscape type Forest land had three data classes for 1980 and 2012: Broad-leaved forest, Coniferous forest, and Mixed forest. The landscape type Scrub/forest succession had four data classes: Continental scrub (moors and heathland); Mediterranean scrub (sclerophyllous vegetation); Transitional woodlandshrub: Sparsely vegetated area. For 1980, the landscape type Water areas had one data class, Water bodies, while for 2012, another data class was added, Water courses. The landscape type Rocky surfaces was only recorded in 1980 and contained one data class, Bare rocks.
}

KiG No. 35, Vol. 20, 2021, https://doi.org/10.32909/kg.20.35.1 - 


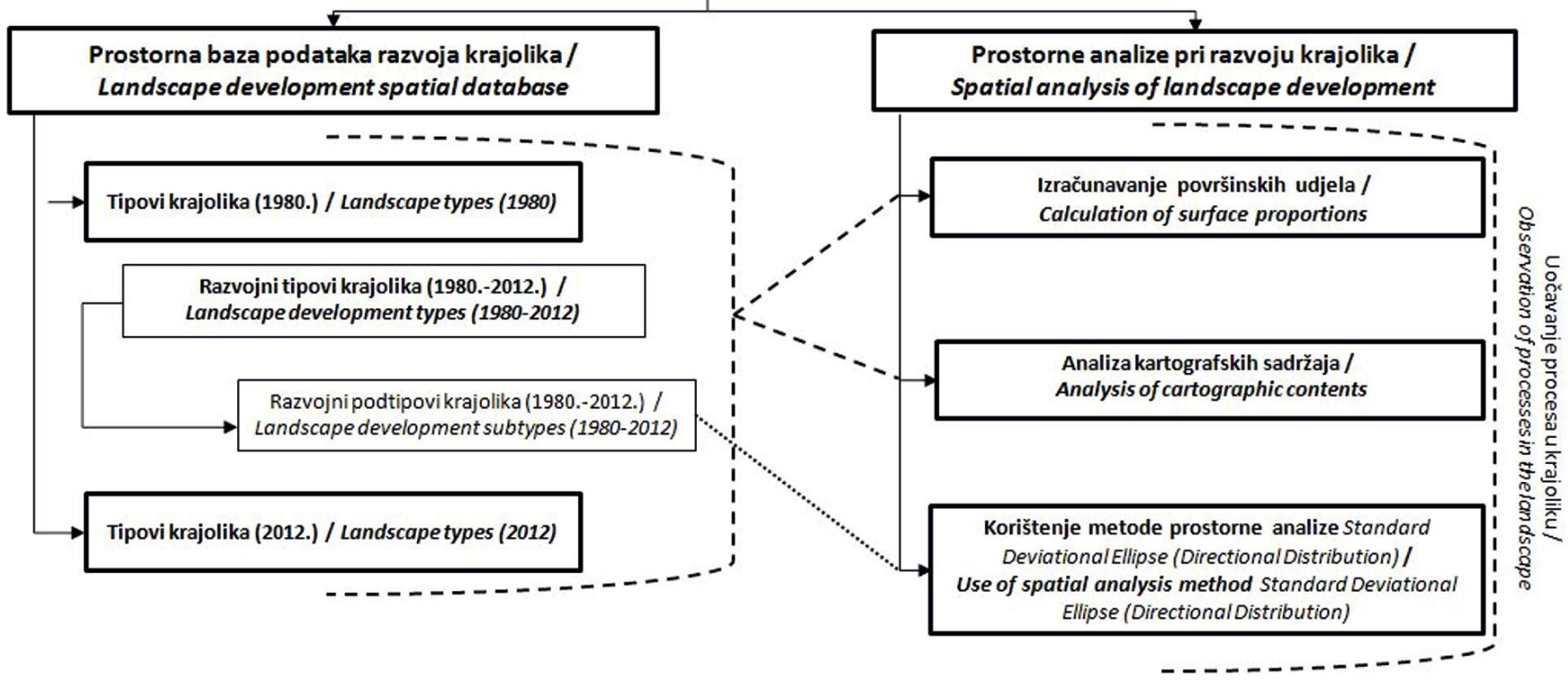

Slika 2. Primijenjeni GIS-model razvoja krajolika Srednje Like.

Fig. 2 Applied GIS landscape development model of Central Lika.

mletački i franciskanski katastar i podatke njegove kasnije revizije, uz primjenu prostorno-analitičkih GIS-alata i statističko-prostorne analize. Durbešić (2012) te Durbešić i Fuerst-Bjeliš (2016) su istraživale promjene krajolika (uglavnom vegetacijskog pokrova) od 19. stoljeća na studiji južne padine Svilaje. U tu su svrhu koristile različite vrste podataka: podatke austrijskog katastra o zemljišnom pokrovu i načinu korištenja zemljišta, bazu podataka CORINE Land Cover, topografske i šumarske karte, satelitske snimke, kao i podatke terenskog istraživanja za najrecentnije razdoblje. Pri tome su definirale tipove pejzaža za tri komparativna perioda od 19. stoljeća do danas te trendove promjena, koji konceptualno odgovaraju razvojnim tipovima krajolika u ovome radu.

U Sloveniji postoji jaka tradicija istraživanja promjena načina korištenja zemljišta bazirana na podatcima franciskanskog katastra za povijesno razdoblje. U kontekstu razvoja krajolika kroz dugi vremenski raspon posebno se ističe rad Geršiča, Gabrovca i Zwittera (2018) u kojem su za područje Hraški Listneki analizirali promjene krajolika od prve polovice 19. stoljeća do danas. U radu su komparativno korišteni podatci jozefinskog i franciskanskog katastra, podatci katastra zemljišta iz 2013. i evidencije stvarne upotrebe poljoprivrednog i šumskog zemljišta iz 2018., podatci digitalnog ortofota, kao i podatci terenskog istraživanja. Također treba istaknuti istraživanje Gabrovca i Kumera (2019) kojim su, također na temelju franciskanskog katastra i baze podataka načina korištenja zemljišta iz 2016., definirali tipove promjena načina korištenja zemljišta i indekse promjene za područje Slovenije od 19. stoljeća.

Proučavanje razvoja krajolika novijeg razdoblja i kraćeg vremenskog raspona omogućuje korištenje novijih i brojnijih vrsta podataka te pristupa i metoda. Esbah (2009) istražila je razvoj krajolika kroz analizu promjena strukturnih obilježja uzoraka krajolika gradskog područja Aydin u Turskoj za dvije promatrane godine (1977. i 2002.). Pri tome je koristila veći broj pokazatelja, odnosno metoda prostorne analize, ali bez uspostave razvojnih tipova i/ili trendova. Lončar i Cvitanović (2012) su također koristili različite vrste podataka i analizirali promjene okoliša Pridravske nizine Osijeka $u$ povezanosti sa socioekonomskim i demografskim faktorima $u$ drugoj polovici 20. stoljeća, također ne određujući pri tome i razvojne tipove $\mathrm{i} / \mathrm{ili}$ trendove promjena. $\mathrm{U}$ radovima Cvitanovića $(2014,2014 a)$ te Cvitanovića i FuerstBjeliš (2018) provedena su istraživanja razvoja krajolika Hrvatskog zagorja za razdoblje 1978-2011, odnosno 1991-2011, bazirana na kombiniranom metodološkom pristupu koji uključuje kvantitativne i kvalitativne podatke i analize, uz deskriptivno-analitičke, prostorno-statističke (GIS), inferencijalnostatističke i empirijske metode istraživanja. MorićŠpanić i Fuerst-Bjeliš (2017) kombinirajući različite podatke za dvije komparativne godine: vegetacijsku 


\begin{tabular}{|c|c|}
\hline $\begin{array}{l}\text { Tipovi krajolika (1980.)/ } \\
\text { Landscape types (1980) }\end{array}$ & $\begin{array}{l}\text { Tipovi krajolika (2012.)/ } \\
\text { Landscape types (2012) }\end{array}$ \\
\hline $\begin{array}{l}\text { TIP 1 - Izgrađeno zemljište / } \\
\text { TYPE 1 - Built-up land }\end{array}$ & $\begin{array}{l}\text { TIP 1 - Izgrađeno zemljište / } \\
\text { TYPE 1 - Built-up land }\end{array}$ \\
\hline $\begin{array}{c}\text { TIP 2 - Travnato zemljište / } \\
\text { TYPE 2 - Grassland }\end{array}$ & $\begin{array}{c}\text { TIP 2 - Travnato zemljište / } \\
\text { TYPE 2 - Grassland }\end{array}$ \\
\hline $\begin{array}{c}\text { TIP 3-Poljoprivredno zem/jište / } \\
\text { TYPE 3 - Agriculturalland }\end{array}$ & $\begin{array}{c}\text { TIP 3-Poljoprivredno zemljište / } \\
\text { TYPE 3-Agriculturalland }\end{array}$ \\
\hline $\begin{array}{l}\text { TIP 4-Šumsko zemljište / } \\
\text { TYPE 4 - Forest land }\end{array}$ & $\begin{array}{l}\text { TIP 4- Šumsko zemljište / } \\
\text { TYPE 4 - Forest land }\end{array}$ \\
\hline $\begin{array}{l}\text { TIP 5- Grmlje/sukcesija šume / } \\
\text { TYPE 5 - Scrub/forest succession }\end{array}$ & $\begin{array}{l}\text { TIP 5 - Grmlje/sukcesija šume / } \\
\text { TYPE 5 - Scrub/forest succession }\end{array}$ \\
\hline $\begin{array}{l}\text { TIP 6 - Vodene površine/ } \\
\text { TYPE 6 - Water areas }\end{array}$ & $\begin{array}{l}\text { TIP 6 - Vodene površine / } \\
\text { TYPE 6 - Water areas }\end{array}$ \\
\hline $\begin{array}{l}\text { TIP 7-Stjenovite površine / } \\
\text { TYPE 7 - Rocky surfaces }\end{array}$ & \\
\hline
\end{tabular}

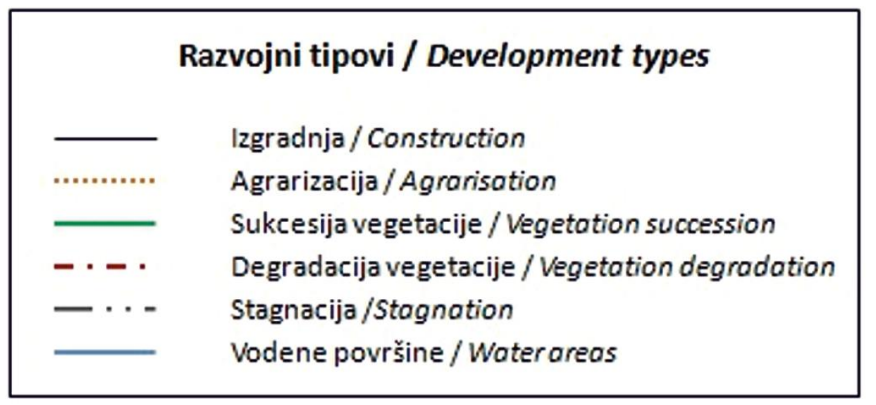

Fig. 3 Conceptual model of landscape development types, 1980-2012.

Slika 3. Konceptualni model razvojnih tipova krajolika za razdoblje 1980-2012.

three subtypes were defined: Vegetation succession, first phase; Vegetation succession, second phase, and Vegetation succession, third phase (Figure 4).

\subsection{Methodological notes on the use of the spatia analysis method in the GIS model of landscape development for Central Lika}

The Standard Deviational Ellipse (Directional Distribution) spatial analysis method was used with the aim of gaining an insight into the spatial distribution of the three phases in the process of vegetation succession. In order to perform the method, the ArcGIS 10.0 computer programme was used.

By applying this method, ellipses with values are obtained (coordinates $X$ and $Y$ for the centre; standard distances for $X$ and $Y$, i.e. radius ellipses; value for rotation). The ellipses describe spatial distribution (central tendency, spatial dispersion, or orientation concentration) (Wong 1999).

Standard Deviational Ellipse (Directional Distribution) is derived by calculating on the basis of the following formulae (ESRI 2020):

$$
\begin{aligned}
& S D E_{x}=\sqrt{\frac{\sum_{i=1}^{n}\left(x_{i}-\bar{X}\right)^{2}}{n}} \\
& S D E_{y}=\sqrt{\frac{\sum_{i=1}^{n}\left(y_{i}-\bar{Y}\right)^{2}}{n}}
\end{aligned}
$$

$x_{i}, y_{i}$ - coordinates for object $i$

$\{\bar{X}, \bar{Y}\}$ - mean centre for objects $n$ - total number of objects

KiG No. 35, Vol. 20, 2021, https://doi.org/10.32909/kg.20.35.1 - - 



Slika 4. Konceptualni model razvojnog tipa Sukcesija vegetacije. Fig. 4 Conceptual model of development type Vegetation succession.

kartu (1975) i CORINE Land Cover, podatke Hrvatskih šuma i digitalne ortofotosnimke (2011), definirale su tipove krajolika i trendove promjene, koji konceptualno također odgovaraju razvojnim tipovima u ovome radu. U novijim se istraživanjima promjena zemljišnog pokrova kontinentske Hrvatske također uvode i metode daljinskih istraživanja te simulacijski model analize i projekcije promjena (Jogun i dr. 2017, Jogun i dr. 2019).

Osim navedenih radova u kojima se proučava razvoj krajolika kroz duži ili kraći vremenski raspon, u pojedinim radovima se određuju tipovi krajolika s obzirom na jednu promatranu vremensku točku, koja se odnosi na korištene podatke. Hrdalo i dr. (2008) za prostor Dubrovačkog primorja svrstali su tipove krajolika s obzirom na namjene i prirodna obilježja prostora pri čemu su izdvojili tri osnovne skupine kulturnih krajobraza: polja, suhozidi kao element ograđivanja i terase. Mücher i dr. (2010) korištenjem četiri vrste podataka (klimatska obilježja, nadmorska visina, sastav tla, zemljišni pokrov i način korištenja zemljišta), od kojih je svaki objavljen u jednoj referentnoj točki, izdvojili su četiri hijerarhijske razine klasifikacije krajolika na razini Europe. Prva razina odnosi se na klimatska obilježja, druga na nadmorsku visinu, treća na sastav tla, a četvrta na zemljišni pokrov i način korištenja zemljišta.

Primjena GIS-modela pri istraživanju različitih (dijelova) krajolika, odnosno pojava u krajoliku, kako je vidljivo, temelji se na različitim vrstama podataka, kao i izvora podataka. Pri tome se analizira stanje za jednu vremensku točka ili pak razvoj unutar dvije ili više vremenskih točki, odnosno vremenskih razdoblja. Manji je udjel istraživanja promjena krajolika, međutim, onaj koji uz promjenu određuje i razvojne tipove krajolika ili trendove razvoja. U 
The angle of rotation is calculated thus:

$$
\begin{aligned}
& \tan \theta=\frac{A+B}{C} \\
& A=\left(\sum_{i=1}^{n} \tilde{x}_{i}^{2}-\sum_{i=1}^{n} \tilde{y}_{i}^{2}\right) \\
& B=\sqrt{\left(\sum_{i=1}^{n} \tilde{x}_{i}^{2}-\sum_{i=1}^{n} \tilde{y}_{i}^{2}\right)^{2}+4\left(\sum_{i=1}^{n} \tilde{x}_{i} \tilde{y}_{i}\right)^{2}} \\
& C=2 \sum_{i=1}^{n} \tilde{x}_{i} \tilde{y}_{i}
\end{aligned}
$$

$\tilde{x} i, \tilde{y} \mathrm{i}$ - deviation of coordinates $x, y$ from the mean centre

Standard deviations for the axes $x$ and $y$ are:

$$
\sigma_{x}=\sqrt{\frac{\sum_{i=1}^{n}\left(\tilde{x}_{i} \cos \theta-\tilde{y}_{i} \sin \theta\right)^{2}}{n}}
$$

$$
\sigma_{y}=\sqrt{\frac{\sum_{i=1}^{n}\left(\tilde{x}_{i} \sin \theta-\tilde{y}_{i} \cos \theta\right)^{2}}{n}}
$$

In this study, the ellipse option was used given the spatial location of each of the observed landscape development subtypes in Central Lika. Ellipses of the different positions, shapes and directions of each of the observed development subtypes were obtained. In fact, taking into account the entire research area, the ellipse of each observed development subtype was concentrated and widened according to the higher concentration of the observed phenomenon, so that the centre of the ellipse was close to that area. On the other hand, taking into account the entire research area, the ellipse of the observed development subtype narrowed according to the lower concentration of the observed phenomenon.

\section{Landscape Types in Central Lika in 1980 and 2012}

Based on the data on land cover and land use from 1980, and according to the procedure outlined above, the area of Central Lika was classified according to seven landscape types. They are: Builtup land, Grassland, Agricultural land, Forest land,
Scrub/forest succession, Water areas and Rocky surfaces (Figure 5).

In the same way, data for 2012 for the area of Central Lika were classified into six landscape types. They are: Built-up land, Grassland, Agricultural land, Forest land, Scrub/forest succession and Water areas (Figure 6).

It is clear that in 2012, six landscapes types were confirmed, while in 1980, there were seven. The seventh relates to Rocky surfaces, which it was no longer possible to distinguish in 2012, indicating the process of vegetation succession.

The landscape type Built-up land refers to road and rail networks and associated land, building sites, industrial and commercial units, and mineral extraction sites. However, within this landscape type, the greatest surface area refers to discontinuous urban areas or settlements. There are 78 settlements in Central Lika, however only a few of them are shown according to the data used: Gospić (shown with the settlements of Budak, Žabica, Kaniža Gospićka, Podoštra), Lički Osik, Perušić, Mušaluk, Donji Kosinj, Lički Novi, Bilaj, Lovinac, and a small part of the settlement of Gračac. The other settlements occupy smaller surface areas, that is, the concentration of buildings is lower, because they are mostly dispersed and consists of several hamlets.

The landscape type Grassland consists of pastures and natural grassland. Their common characteristic is the presence of various types of grass which are low-growing, either due to natural conditions or cattle-grazing. However, they differ in terms of location and features. The pastures are areas of lowerquality soil, grass and scrub which are used to graze cattle (sheep, cows, goats and horses). In terms of their position, they can be said to surround the agricultural land which is situated close to the settlements. Natural grasslands are areas where various types of grass grow naturally, and due to natural conditions (poorer soil, more rocks, steep terrains, slopes in shadows) no other kind of plant cover can be established.

The landscape type Agricultural land in both observation years (1980 and 2012) was mostly located in the administrative area of the town of Gospić. This is in line with positive demographic indicators (immigration, overall population growth). On the other hand, there are only a few smaller agricultural areas in the municipalities of Perušić and Lovinac. These are mostly used to grow agricultural products for personal use, with only a few rare examples of cultivation for industrial production.

KiG No. 35, Vol. 20, 2021, https://doi.org/10.32909/kg.20.35.1 - - 
Tipovi krajolika Srednje Like (1980.)

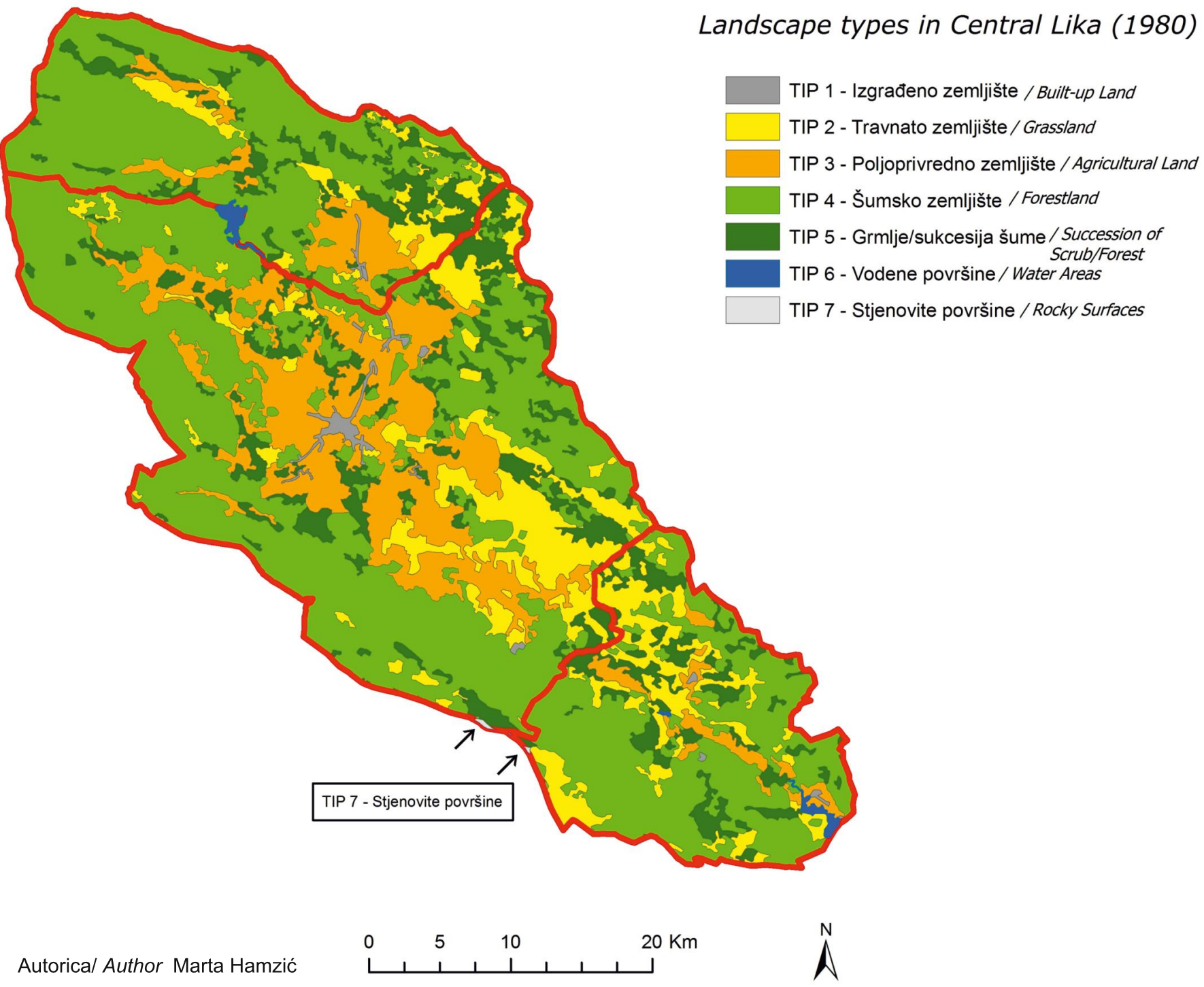

Slika 5. Tipovi krajolika Srednje Like (1980. godina), izvor: CLC 1980, HAOP; SRPJ, DGU.

Fig. 5 Landscape types in Central Lika (1980), source: CLC 1980, HAOP; SRPJ, DGU.

ovome radu je osim definiranja razvojnih tipova krajolika, koji odgovaraju uočenim trendovima razvoja, primijenjena metoda prostorne analize Elipse standardnih devijacija (Distribucija smjerova) koja omogućuje određivanje prostorne distribucije razvojnih podtipova krajolika.

\subsection{Područje istraživanja}

Područje istraživanja je Srednja Lika, koja je prema aktualnoj administrativno-teritorijalnoj organizaciji prostorno obuhvaćena $u$ tri jedinice lokalne samouprave: Grad Gospić, Općinu Lovinac i Općinu Perušić, a koje su sastavni dio Ličko-senjske županije.
Ukupna površina područja istraživanja iznosi približno $1690 \mathrm{~km}^{2}$. Grad Gospić zauzima površinu od 967 km² , dok su površinski manje Općina Perušić (381 $\left.\mathrm{km}^{2}\right)$ i Općina Lovinac $\left(342 \mathrm{~km}^{2}\right)$. Na području istraživanja nalazi se 78 naselja, od toga administrativnom području Grada Gospića pripada 50 naselja, Općini Perušić 18 naselja i Općini Lovinac 10 naselja (slika 1).

Srednja je Lika u razdoblju od završetka Drugog svjetskog rata značajno pogođena iseljavanjem i starenjem stanovništva, deagrarizacijom te deruralizacijom i urbanizacijom. Depopulacija i promjena načina života nužno se izravno, a također i značajno reflektirala na način korištenja zemljišta i promjenu krajolika, u kojem dominiraju procesi ekstenzifikacije. 




Fig. 6 Landscape types in Central Lika (2012), source: CLC 2012, HAOP; SRPJ, DGU; Topographic maps, DGU.

Slika 6. Tipovi krajolika Srednje Like (2012. godina), Izvor: CLC 2012, HAOP; SRPJ, DGU;Topografske karte, DGU. 


\section{Metodološke napomene}

GIS-model razvoja krajolika Srednje Like sastoji se od prostornih podataka koji su sadržani u prostornoj bazi podataka razvoja krajolika i prostornih analiza za detekciju procesa u krajoliku (slika 2). U nastavku rada nalaze se metodološke napomene uz korištenje podataka i metode prostorne analize.

\subsection{Metodološke napomene uz upotrebu podataka u GIS-modelu razvoja krajolika Srednje Like}

Pri izradi GIS-modela razvoja krajolika korištene su dvije baze podataka - CORINE Land Cover 1980 (CLC 1980) i CORINE Land Cover 2012 (CLC 2012). Na europskoj razini te se baze izrađuju u okviru projekta Copernicus Land Monitoring Service, a dio tih baza koji se odnosi na Republiku Hrvatsku su proizvod Hrvatske agencije za okoliš i prirodu (HAOP). Navedene baze podataka izrađene su prema standardnom pristupu izrade baze podataka CLC, koji se temelji na vizualnoj interpretaciji satelitskih snimaka prema prihvaćenoj CLC metodologiji. Tako se stvaraju podatci u vektorskom modelu podataka u mjerilu 1:100 000, minimalne širine poligona 100 metara za linearne entitete (linije) i 25 ha za površinske entitete (poligone). Pri tome je od velike važnosti istaknuti kako $\mathrm{u}$ bazu podataka nisu uneseni svi dijelovi. Tako, na primjer, kod tipa krajolika Izgrađeno zemljište nisu vidljiva manja naselja, jer se kod takvih naselja ne zadovoljava kriterij dovoljne koncentracije objekata u odnosu na rezoluciju rešetke. Također, kod ovog tipa krajolika zbog nedovoljne širine objekta u odnosu na rešetku, nisu vidljive druge prometnice osim autoceste. $U$ namjeri što vjernijeg utvrđivanja tipova i razvojnih tipova krajolika Srednje Like, podatci navedenih baza podataka korišteni su kao činjenični te su kao takvi analizirani u radu.

Na području Srednje Like je, prema postupku navedenom $u$ uvodnom dijelu ovog rada, unutar baze podataka CLC 1980 evidentirano 17 klasa podataka koje su svrstane u sedam tipova krajolika, dok je unutar baze podataka CLC 2012 evidentirano 19 klasa podataka koje su svrstane u šest tipova krajolika. ${ }^{3}$ Evidentno je kako za 1980. nisu zabilježene neke od klasa podataka koje su utvrđene za 2012. S druge strane, za 2012. nedostaje jedan od tipova krajolika Stjenovite površine koji je utvrđen za 1980.

Razvojni tipovi krajolika Srednje Like za promatrano razdoblje 1980-2012 određeni su na temelju usporedbe tipova krajolika za svaku pojedinu godinu prema konceptualnom modelu razvojnih tipova krajolika (slika 3). Pri tome je definirano šest razvojnih tipova krajolika: Izgradnja, Agrarizacija, Sukcesija vegetacije, Degradacija vegetacije, Stagnacija, Vodene površine. Nadalje, unutar razvojnog tipa Sukcesija vegetacija definirana su tri razvojna podtipa: Sukcesija vegetacije prve faze, Sukcesija vegetacije druge faze i Sukcesija vegetacije treće faze (slika 4).

\subsection{Metodološke napomene uz metodu prostorne analize u GIS-modelu razvoja krajolika Srednje Like}

Metoda prostorne analize Elipse standardnih devijacija (Distribucija smjerova) korištena je s ciljem stjecanja uvida u prostornu distribuciju triju faza procesa sukcesije vegetacije. Metoda je sastavni dio računalnog programa ArcGIS verzije 10.0.

Tom metodom dobivaju se elipse s odgovarajućim vrijednostima (koordinate $X$ i $Y$ za centar; standardne devijacije za $X$ i $Y$, tj. radijuse elipse; vrijednosti za rotaciju). Elipse ocrtavaju prostornu distribuciju (centralnu tendenciju, prostornu raspršenost, odnosno koncentraciju te orijentaciju) (Wong 1999).

Elipse standardnih devijacija (Distribucija smjerova) dobivaju se računanjem na temelju sljedećih formula (ESRI 2020):

$$
\begin{aligned}
& S D E_{x}=\sqrt{\frac{\sum_{i=1}^{n}\left(x_{i}-\bar{X}\right)^{2}}{n}} \\
& S D E_{y}=\sqrt{\frac{\sum_{i=1}^{n}\left(y_{i}-\bar{Y}\right)^{2}}{n}}
\end{aligned}
$$

\footnotetext{
${ }^{3}$ Nakon provedenog postupka, za 1980. godinu tip krajolika Izgrađeno zemljište sadrži tri klase podataka: Nepovezana gradska područja; Industrijski ili komercijalni objekti; Mjesta eksploatacije mineralnih sirovina. Za 2012. godinu tip krajolika Izgrađeno zemljište sadrži još dvije klase podataka: Cestovna i željeznička mreža i pripadajuće zemljište; Gradilišta. Tip krajolika Travnato zemljište za 1980. i 2012. sadrži dvije klase podataka: Pašnjaci; Prirodni travnjaci. Tip krajolika Poljoprivredno zemljište za 1980. i 2012. sadrži tri klase podataka: Nenavodnjavano obradivo zemljište; Mozaik poljoprivrednih površina; Pretežno poljoprivredno zemljište, sa značajnim udjelom prirodnog biljnog pokrova. Tip krajolika Šumsko zemljište za 1980. i 2012. sadrži tri klase podataka: Bjelogorična šuma; Crnogorična šuma; Mješovita šuma. Tip krajolika Grmlje i sukcesija šume sadrži četiri klase podataka: Kontinentalna grmolika vegetacija (vrištine, cretovi i niske šikare); Mediteranska grmolika vegetacija (sklerofilna); Sukcesija šume (zemljišta u zarastanju); Područja s oskudnom vegetacijom. Za 1980. godinu tip krajolika Vodene površine sadrži jednu klasu podataka - Vodna tijela, dok za 2012. godinu sadrži još jednu klasu podataka - Vodotoci. Tip krajolika Stjenovite površine zabilježen je samo za 1980. godinu, te sadrži jednu klasu podataka - Gole stijene.
} 
The landscape type Forest land is mostly found on the margins of the research area (Figure 5). Broadleaved forests are the natural vegetation cover in this area. However, real forests have only been preserved on the slopes of Velebit and on the high, less accessible parts of Ličko sredogorje (Pejnović, 1985). In earlier periods, as the number of people engaged in agriculture grew, this led to the destruction of the natural vegetation cover. The broad-leaved forests were suppressed in favour of extending arable land particularly in Ličko polje and on suitable slopes. Today, broad-leaved forests are found in Ličko polje and on the lower slopes of the relief frame, while the upper slopes are covered in coniferous and mixed forests. Like the broad-leaved forests, coniferous and mixed forests in Central Lika are mostly natural (wild) forests, while plantations occupy smaller areas. Most of the forests are state-owned, with only a few private forests. ${ }^{4}$

The landscape type Scrub/forest succession is characterised by various kinds of medium high vegetation. It is the result of agricultural land being neglected or abandoned and the development of the second phase of succession. In addition, it is found on bases which have been impoverished of mineral contents, where the third phase of vegetation succession cannot develop, that is, tall vegetation (forests). However, in the locations where the soil quality is sufficient, in the conditions of existing socioeconomic processes, it may gradually grow into forests.

The area of Central Lika has an abundance of water. It is found in a large number of large and small springs, sources, water courses and water bodies. However, the data used show that only a few objects belong to the Water areas landscape type: one watercourse (the subterranean River Lika) and three water

\footnotetext{
${ }^{4}$ In the state-owned forests, the most common trees are beeches and pines (Abieti-Fagetum Illyricum), which are also the most important trees for industrial production. According to the different natural conditions prevalent in Central Lika, different types of forests are present. In Ličko polje, at low elevations above sea level, most of the broad-leaved forests consist of sessile oak and common hornbeam (Querco petraeaeCarpinetum illyricum), while by the watercourses, there are smaller forests of hydrophilic types of black alder and reeds (Carici brizoidis-Alnetum), grey willow (Salix cinerea) and purple osier (Salix purpurea). At higher elevations above sea level, above the hilly beech forests (Fagetum illyricum montanum), in central and northern Velebit, beech and pine forests continue (Abieti-Fagetum illyricum), while in the highest parts there are pre-mountainous beech forests (Fagetum illyricum subalpinum) (Pelcer and Martinović 2003).
}

bodies (Lake Krušić, Lake Štikada, and Lake Ričice, a retention of the subterranean River Obsenica). The other water bodies are very small in size, or are not large enough to be noted with the data used.

\section{Landscape Development Types in Central Lika 1980-2012}

According to the GIS model of landscape development in Central Lika ${ }^{5}$ for the period 1980-2012, six landscape development types and six subtypes were determined. The landscape development types in Central Lika for 1980-2012 are (Figure 7):

1. Construction (land which has been repurposed from other land cover/land use for building)

2. Agrarisation (land which has been repurposed from other land cover/land use for agriculture)

3. Vegetation succession (land which has changed from other land cover/land use into grassland, scrub/forest succession, or forest land)

4. Vegetation degradation (land which has changed from scrub/forest succession or forest land into grassland or scrub/vegetation succession)

5. Stagnation (land which has not been repurposed or changed, but has retained the same land cover/land use)

6. Water areas (land which was under water in one of the observed years).

Since the process of vegetation succession occurs in three phases, three landscape development subtypes for the development type Vegetation succession were defined for the period 1980-2012. In addition, the spatial analysis method Standard Deviational Ellipse (Directional Distribution) confirmed the spatial distribution of each of the phases of vegetation succession, shown graphically in ellipses of location (Figure 8). The landscape development subtypes of Central Lika are:

1) Vegetation succession, first phase (land which has changed from other land cover/land use into grassland) (Figure 9)

2) Vegetation succession, second phase (land which has changed from other land cover/ land use into scrub/vegetation succession) (Figure 10)

3) Vegetation succession, third phase (land which has changed from other land cover/ land use into forest land)

\footnotetext{
${ }^{5}$ In the chapter 2.2 Methodological notes on the use of the spatial analysis method in the GIS model of landscape development for Central Lika.
}

KiG No. 35, Vol. 20, 2021, https://doi.org/10.32909/kg.20.35.1 - 
Razvojni tipovi krajolika

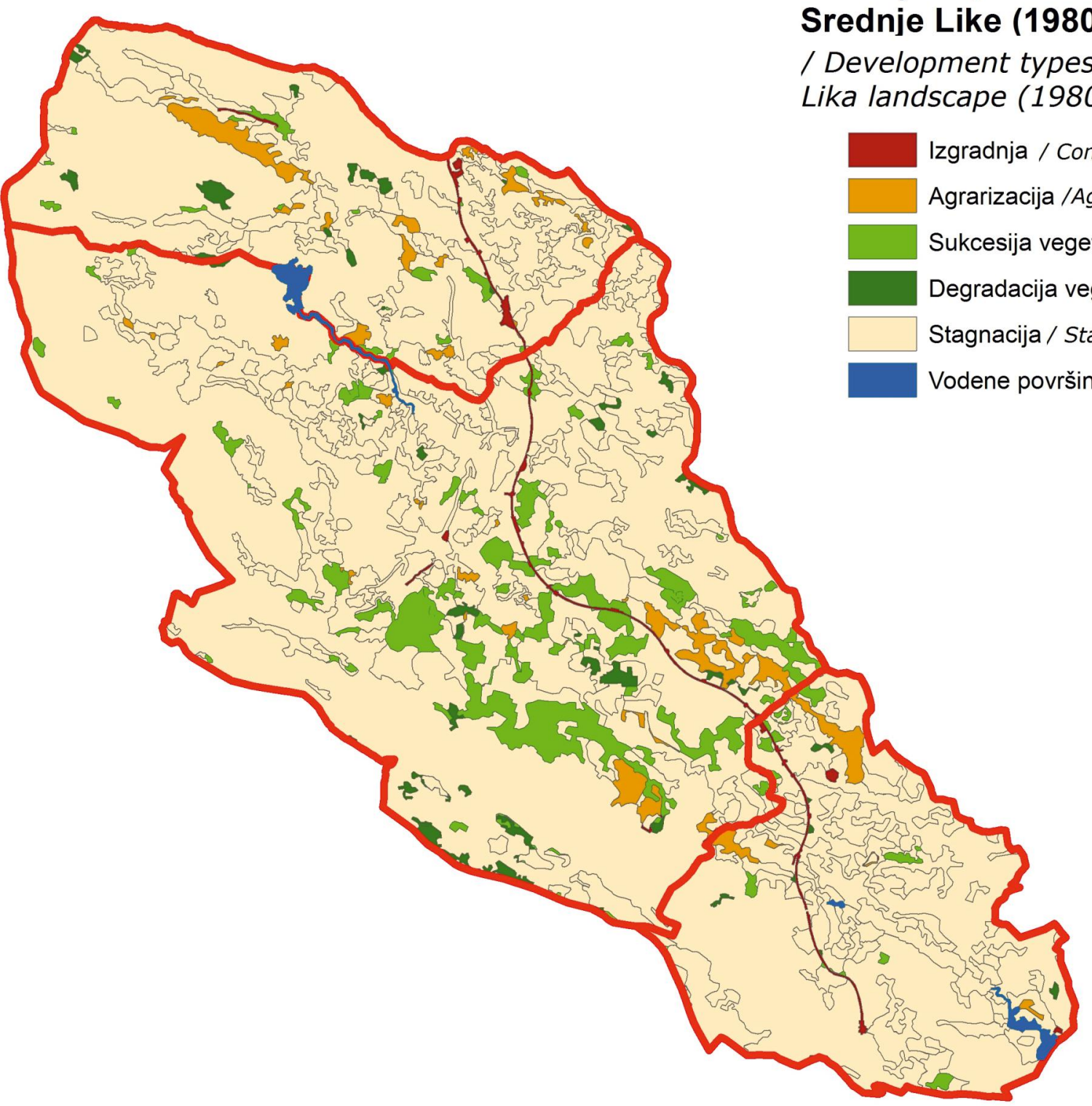

Autorica/ Author Marta Hamzić



$\Lambda$

Slika 7. Razvojni tipovi krajolika Srednje Like (1980-2012), izvor: CLC 2012, HAOP; SRPJ, DGU.

Fig. 7 Landscape development types in Central Lika (1980-2012), source: CLC 2012, HAOP; SRPJ, DGU.

$x_{i}, y_{i}-$ koordinate za objekt $i$

$\{\bar{X}, \bar{Y}\}$ - središte

$n$ - ukupan broj objekata

$A=\left(\sum_{i=1}^{n} \tilde{x}_{i}^{2}-\sum_{i=1}^{n} \tilde{y}_{i}^{2}\right)$

Kut rotacije računa se po formuli:

$\tan \theta=\frac{A+B}{C}$

$B=\sqrt{\left(\sum_{i=1}^{n} \tilde{x}_{i}^{2}-\sum_{i=1}^{n} \tilde{y}_{i}^{2}\right)^{2}+4\left(\sum_{i=1}^{n} \tilde{x}_{i} \tilde{y}_{i}\right)^{2}}$ 




Fig. 8 Vegetation succession development subtypes and ellipses of spatial location (1980-2012).

Slika 8. Razvojni podtipovi i elipse prostornog razmještaja Sukcesije vegetacije (1980-2012).

The landscape development type Construction covers only $0.63 \%$ of Central Lika. This is land which has been repurposed from other land cover/land use into building land. In the observation period (1980-2012), most such land was formerly grassland or agricultural land. This refers to the extension of built-up land around Gospić and the settlement of Donji Kosinj, and to the construction of infrastructure (to be more precise, stretches of the A1 highway) and associated objects, the opening of enterprise zones and excavation sites.

The landscape development type Agrarisation accounts for $2.58 \%$ of Central Lika, and mostly refers to land which has been repurposed from grassland for agriculture, predominantly in the northwest and southwest part of the research area, or which has been repurposed from scrub/forest succession for agriculture, as noted in the southeast part of the research area. In that area, in the observation period, family farms were established which are engaged in growing crops and cattle-breeding (sheep, cows, goats, etc).

Vegetation succession is a landscape development type which covers $5.55 \%$ of Central Lika. In the ob- servation period, land cover/land use changed from other categories to grassland, scrub/forest succession, or forest land. In terms of its location, it was established that this landscape development type is found in the south part of the town of Gospić area.

Vegetation succession, first phase, as a development subtype, applies to $1.18 \%$ of Central Lika, where land cover/land use has changed from other categories to grassland. This development subtype mostly refers to agricultural land which has turned into grassland as a result of a reduction in agricultural activities (Table 1).

In Central Lika, 3.11\% of the land has turned into scrub/vegetation succession, which is defined as the landscape development subtype Vegetation succession, second phase. The most significant feature is the change from agricultural land or grassland to scrub/forest succession (Table 1).

The landscape development subtype Vegetation succession, third phase, relates to $1.26 \%$ of Central Lika, where the land has turned into forest land. The most significant aspects are the change from scrub/forest succession (second phase) and from grassland and agricultural land (first phase).

KiG No. 35, Vol. 20, 2021, https://doi.org/10.32909/kg.20.35.1 - - 
$C=2 \sum_{i=1}^{n} \tilde{x}_{i} \tilde{y}_{i}$

$\tilde{x}_{i} \tilde{y}_{i}$ - devijacije koordinata $x, y$ od središta

Standardne devijacije u smjeru koordinatnih osi su:

$\sigma_{x}=\sqrt{\frac{\sum_{i=1}^{n}\left(\tilde{x}_{i} \cos \theta-\tilde{y}_{i} \sin \theta\right)^{2}}{n}}$

$\sigma_{y}=\sqrt{\frac{\sum_{i=1}^{n}\left(\tilde{x}_{i} \sin \theta-\tilde{y}_{i} \cos \theta\right)^{2}}{n}}$

U radu je korištena opcija elipsa s obzirom na prostorni razmještaj (lokacija) svakog od promatranih razvojnih podtipova krajolika Srednje Like. Pri tome su dobivene elipse različitog položaja, oblika i smjera za svaki razmatrani razvojni podtip. Naime, uzimajući u obzir cijelo područje istraživanja, elipsa pojedinog razmatranog razvojnog podtipa se usmjerava i širi prema većoj koncentraciji promatrane pojave, te se središte elipse nalazi bliže tom području. S druge strane, uzimajući u obzir cijelo područje istraživanja, elipsa razmatranog razvojnog podtipa se sužava prema manjoj koncentraciji promatrane pojave.

\section{Tipovi krajolika Srednje Like za godine 1980 . i 2012.}

Na temelju podataka o zemljišnom pokrovu i načinu korištenja zemljišta iz 1980. godine, prema prethodno prikazanom postupku, područje Srednje Like svrstano je u sedam tipova krajolika. To su: Izgrađeno zemljište, Travnato zemljište, Poljoprivredno zemljište, Šumsko zemljište, Grmlje/sukcesija šume, Vodene površine, Stjenovite površine (slika 5).

$\mathrm{Na}$ isti je način korištenjem podataka iz 2012. godine područje Srednje Like svrstano $u$ šest tipova krajolika. To su: Izgrađeno zemljište, Travnato zemljište, Poljoprivredno zemljište, Šumsko zemljište, Grmlje/sukcesija šume, Vodene površine (slika 6).

Vidljivo je kako je za 2012. utvrđeno šest tipova krajolika, dok je za 1980. utvrđeno sedam tipova. Razlika se odnosi na tip krajolika Stjenovite površine koji se 2012. više nije mogao izdvojiti, što ukazuje na proces vegetacijske sukcesije.

$\mathrm{Na}$ tip krajolika Izgrađeno zemljište odnose se cestovna i željeznička mreža i pripadajuće zemljište; gradilišta, industrijski ili komercijalni objekti; mjesta eksploatacije mineralnih sirovina. Međutim, unutar tog tipa krajolika najveća površina odnosi se na nepovezana gradska područja, odnosno naselja. Na području Srednje Like nalazi se 78 naselja, međutim prema korištenim podatcima prikazano ih je tek nekoliko: Gospić (prikazan je s naseljima: Budak, Žabica, Kaniža Gospićka, Podoštra), Lički Osik, Perušić, Mušaluk, Donji Kosinj, Lički Novi, Bilaj, Lovinac, te manji dio naselja Gračac. Preostala naselja se nalaze na manjoj površini, odnosno imaju manju koncentraciju izgrađenosti, jer su uglavnom raštrkana (disperzna) i sastoje se od nekoliko zaselaka.

Tip krajolika Travnato zemljište sastoji se od pašnjaka i prirodnih travnjaka. Zajedničko im je obilježje različite vrsta trava koje zbog prirodnih preduvjeta ili zbog ispaše stoke nisu visokog rasta. Ipak, među njima postoji razlika u položaju i obilježjima. Pašnjaci su područja manje kvalitetnog tla i trava i niskog raslinja koje služe za ispašu stoke (ovce, krave, koze, konji). S obzirom na položaj, može se reći da pašnjaci „okružuju“ poljoprivredna zemljišta, koja se nalaze bliže naseljima. Prirodni travnjaci su područja na kojima prirodno rastu razne vrste trava i gdje zbog prirodnih preduvjeta (tlo manje kvalitetnog sastava, značajan udio kamenja, strmi teren, osojne padine) ne postoji mogućnost stvaranja drugog zemljišnog pokrova.

Tip krajolika Poljoprivredno zemljište u obje promatrane godine (1980. i 2012.) većinom se nalazi na administrativnom području Grada Gospića. To je u skladu s pozitivnim demografskim pokazateljima (imigracija, porast ukupnog broja stanovnika). S druge strane, na području općina Perušić i Lovinac mogu se uočiti tek manje površine pod poljoprivrednim zemljištem. Na njima se najčešće uzgajaju poljoprivredni proizvodi za vlastite potrebe, a rjeđi su primjeri uzgoja za industrijsku proizvodnju.

Tip krajolika Šumsko zemljište uglavnom se nalazi na rubnim dijelovima područja istraživanja (slika 6). Bjelogorična šuma je prirodni vegetacijski pokrov tog područja. Međutim, te prave šume sačuvane su samo na padinama Velebita i na višim, slabije pristupačnim dijelovima Ličkog sredogorja (Pejnović 1985). Naime, u ranijim razdobljima, povećanjem broja stanovnika koji su se uglavnom bavili poljoprivredom, došlo je do destrukcije prirodnog vegetacijskog pokrova. Tada su bjelogorične šume potisnute na račun širenja poljoprivrednog zemljišta, pogotovo u Ličkom polju te na povoljnijim padinama. Danas se bjelogorične šume nalaze $u$ Ličkom polju te nižim padinama reljefnog okvira, dok se na višim padinama nalaze crnogorične i mješovite šume. Kao i bjelogorične, tako i crnogorične te mješovite šume na području Srednje Like pretežno su prirodne (samonikle) šume, a zasađene 


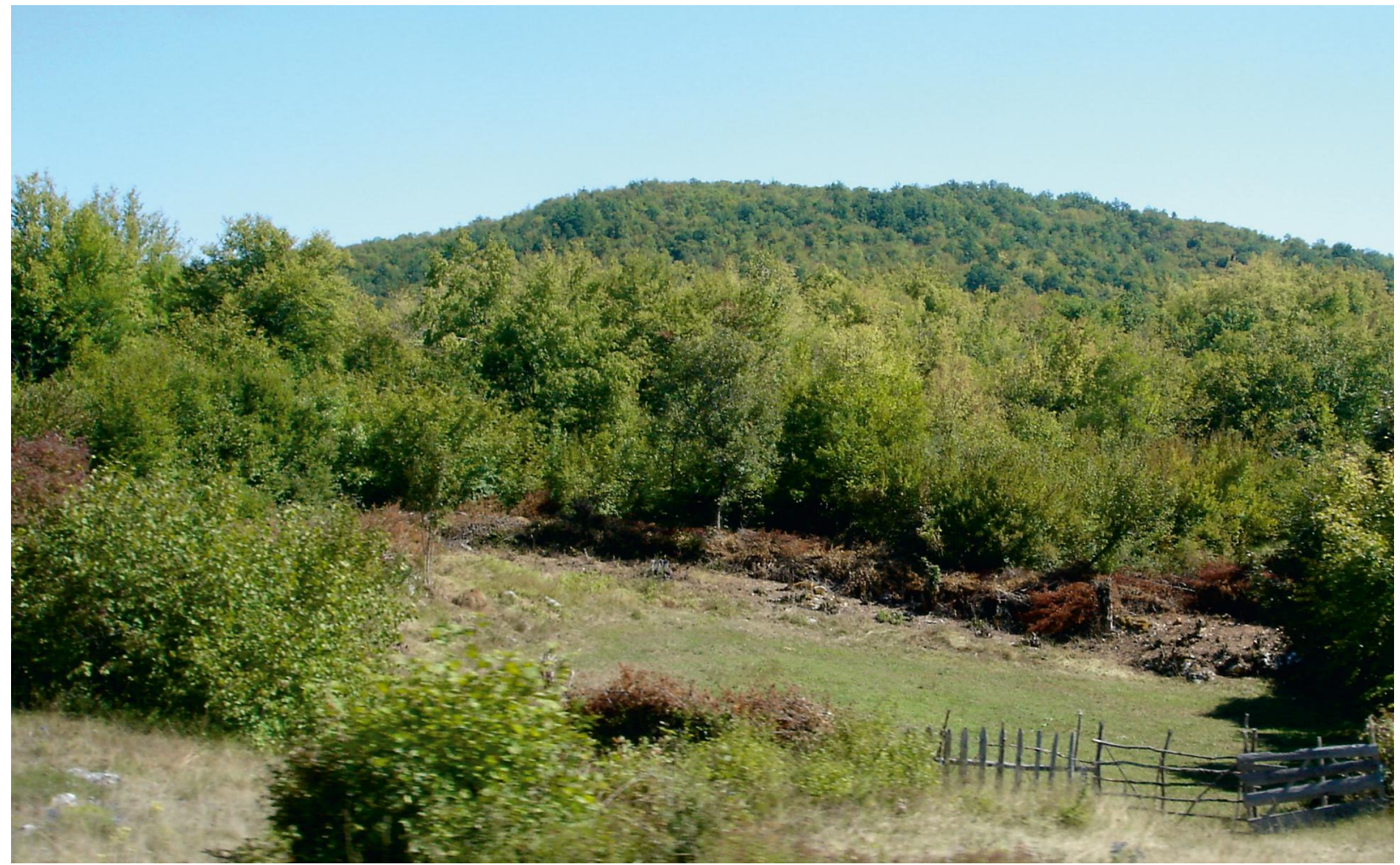

Fig. 9 Succession vegetation, first phase development subtype - abandoned arable land which has turned into grassland through vegetation succession, photo by M. Hamzić (6 September 2013).

Slika 9. Razvojni podtip Sukcesija vegetacije prve faze - napušteno obradivo zemljište vegetacijskom sukcesijom promijenjeno u travnato (snimila M. Hamzić 6. 9. 2013.).

Using the spatial analysis method Standard Deviational Ellipse (Directional Distribution), the spatial distribution of the three phases of vegetation succession for the period 1980-2012 was analysed in more detail. The spatial gradation of the confirmed vegetation succession phases (development subtypes) was established, from the central parts to the margins of the research area. It is evident (yellow ellipse in Figure 8) that the development subtype Vegetation succession, first phase, is found near the central part of the research area, that is, in the area of the town of Gospić, where there has been the least reduction in the number of inhabitants and where the least (and latest) decline in agricultural activities has been noted. On the other hand, the development subtype Vegetation succession, third phase, is found on the margins (dark green ellipse in Figure 8), where the population decline has been mostly expressed, changes in land use (agriculture) began earliest, and because of the long period of vegetation succession, forest land has developed. The development subtype Vegetation succession, second phase, is found between the other two (green ellipse in Figure 8) and shows transitional features.

The landscape development type Vegetation degradation refers to $1.31 \%$ of Central Lika, where in the observation period scrub/forest succession or forest land changed into grassland or scrub/vegetation succession. At the same time, the dominant change is from forest land to scrub/vegetation succession. In terms of location, this development type is spread throughout the entire research area.

Stagnation is a development type which applies to the majority (89.46\%) of Central Lika and is therefore dominant. It covers areas which have not changed or been repurposed. In terms of location, this landscape development type is found throughout the entire research area, although it is least present in the central part of the town of Gospić.

The landscape development type Water areas applies to $0.47 \%$ of Central Lika and covers areas which were under water in one of the observation years. It refers to water bodies (Lake Kruščica, Lake Štikada, Sveti Rok) and the lower part of the subterranean River Lika.

\section{Discussion and Concluding Remarks}

With the aim of establishing landscape development types and subtypes and the spatial gradation of three phases of vegetation succession in Central

KiG No. 35, Vol. 20, 2021, https://doi.org/10.32909/kg.20.35.1 - - 
se nalaze na manjim površinama. Prevladavaju državne šume, dok je privatnih šuma mnogo manje. ${ }^{4}$

Tip krajolika Grmlje/sukcesija šume obilježavaju različite vrste srednje visokog raslinja. On je posljedica zapuštanja i napuštanja poljoprivrednog zemljišta i razvoja druge faze sukcesije. Dodatno, nalazi se na podlogama koje su također osiromašene s mineralnim sastojcima gdje se ne može razviti treća faza sukcesija vegetacije, tj. visoko raslinje (šuma). Međutim, na lokacijama gdje postoji zadovoljavajuća kvaliteta tla u uvjetima postojećih društveno-gospodarskih procesa, postepeno će prerastati u šume.

Područje Srednje Like bogato je vodom. Tamo se nalazi veliki broj manjih ili većih vrela, izvora, vodotoka i vodnih tijela. Međutim, korišteni podatci ukazuju na to da tipu krajolika Vodene površine pripada tek nekoliko objekata: jedan vodotok (ponornica Lika) i tri vodna tijela (Krušičko jezero, jezero Štikada s jezerom Ričice, retencija na ponornici Obsenica). Preostali vodni objekti su vrlo male su površine, odnosno nisu dovoljno široki te s korištenim podatcima nisu zabilježeni.

\section{Razvojni tipovi krajolika Srednje Like za razdoblje 1980-2012}

Prema GIS-modelu razvoja krajolika Srednje Like ${ }^{5}$ za razdoblje 1980-2012 određeno je šest razvojnih tipova i tri razvojna podtipa krajolika Srednje Like. Razvojni tipovi krajolika Srednje Like za razdoblje 1980-2012 su (slika 7):

1. Izgradnja (prenamijenjeno zemljište iz drugih zemljišnih pokrova i načina korištenja zemljišta u izgrađeno zemljište)

2. Agrarizacija (prenamijenjeno zemljište iz drugih zemljišnih pokrova i načina korištenja zemljišta u poljoprivredno zemljište)

\footnotetext{
${ }^{4} \mathrm{U}$ državnim šumama najviše su zastupljene šume bukve jele (Abieti-Fagetum illyricum), koje su ujedno najznačajnije za industrijsku proizvodnju. Sukladno različitim prirodnim uvjetima na području Srednje Like rastu različite vrste šuma. U Ličkom polju na nižim nadmorskim visinama pretežno se nalaze bjelogorične šume hrasta kitnjaka s običnim grabom (Querco petraeae-Carpinetum illyricum), a uz vodotoke su zastupljene manje površine pod šumama hidrofilnih vrsta crne johe sa šašom (Carici brizoidis-Alnetum), sive vrbe (Salix cinerea) i rakite (Salix purpurea). Na višim nadmorskim visinama iznad brdskih bukovih šuma (Fagetum illyricum montanum) na području srednjeg i sjevernog Velebita nastavljaju se šume bukve i jele (Abieti-Fagetum illyricum), a u najvišim dijelovima pretplaninske šume bukve (Fagetum illyricum subalpinum) (Pelcer i Martinović 2003).

${ }^{5} \mathrm{U}$ poglavlju Metodološke napomene uz korištenje podataka u GIS-modelu razvoja krajolika Srednje Like.
}

3. Sukcesija vegetacije (promijenjeno zemljište iz drugih zemljišnih pokrova i načina korištenja zemljišta u: travnato zemljište, grmlje/sukcesija šume ili šumsko zemljište)

4. Degradacija vegetacije (promijenjeno zemljište iz grmlja/sukcesije šume ili šumskog zemljišta $u$ travu ili grmlje/sukcesija vegetacije)

5. Stagnacija (zemljište nije prenamijenjeno, odnosno promijenjeno, nego je istog zemljišnog pokrova i načina korištenja zemljišta)

6. Vodene površine (zemljište koje je $u$ jednoj od promatranih godina bilo pod vodenom površinom).

$\mathrm{S}$ obzirom na to da se proces vegetacijske sukcesije odvija kroz tri faze, za razvojni tip Sukcesija vegetacije definirana su tri razvojna podtipa krajolika za razdoblje 1980-2012. Također, metodom prostorne analize Elipse standardnih devijacija (Distribucija smjerova) utvrđena je prostorna distribucija svake od faza procesa vegetacijske sukcesije, grafički prikazana elipsama razmještaja (slika 8). Utvrđeni razvojni podtipovi krajolika Srednje Like su:

1) Sukcesija vegetacije prve faze (promijenjeno zemljište iz drugih zemljišnih pokrova i načina korištenja zemljišta u travnato zemljište) (slika 9)

2) Sukcesija vegetacije druge faze (promijenjeno zemljište iz drugih zemljišnih pokrova i načina korištenja zemljišta u grmlje/sukcesija vegetacije) (slika 10)

3) Sukcesija vegetacije treće faze (promijenjeno zemljište iz drugih zemljišnih pokrova i načina korištenja zemljišta u šumsko zemljište)

Razvojni tip krajolika Izgradnja odnosi se na tek 0,63 \% područja Srednje Like. To je prenamijenjeno zemljište iz drugih zemljišnih pokrova i načina korištenja zemljišta u izgrađeno zemljište. Pri tome je $\mathrm{u}$ promatranom razdoblju (1980-2012) najviše došlo do prenamjene travnatog i poljoprivrednog u izgrađeno zemljište. To se odnosi na proširenje izgrađenog zemljišta uz Gospić i naselje Donji Kosinj te na izgradnju prometne infrastrukture (preciznije dionicu autoceste A1) i na pripadajuće objekte, otvaranje poduzetničkih zona i eksploatacijskih iskopa.

Razvojni tip krajolika Agrarizacija čini $2,58 \%$ područja Srednje Like, a najviše se odnosi na prenamje$\mathrm{nu}$ iz travnatog zemljišta $u$ poljoprivredno, $i$ to pretežno u sjeverozapadnom i jugozapadnom području istraživanja, kao i na prenamjenu iz grmlja/sukcesije šume u poljoprivredno zemljište, što je utvrđeno $u$ jugoistočnom dijelu istraživanog područja. Naime, na tom području su u promatranom razdoblju otvorena obiteljska poljoprivredna gospodarstva, koja se bave poljodjelstvom i stočarstvom (uzgojem npr. ovaca, krava, koza i dr.). 


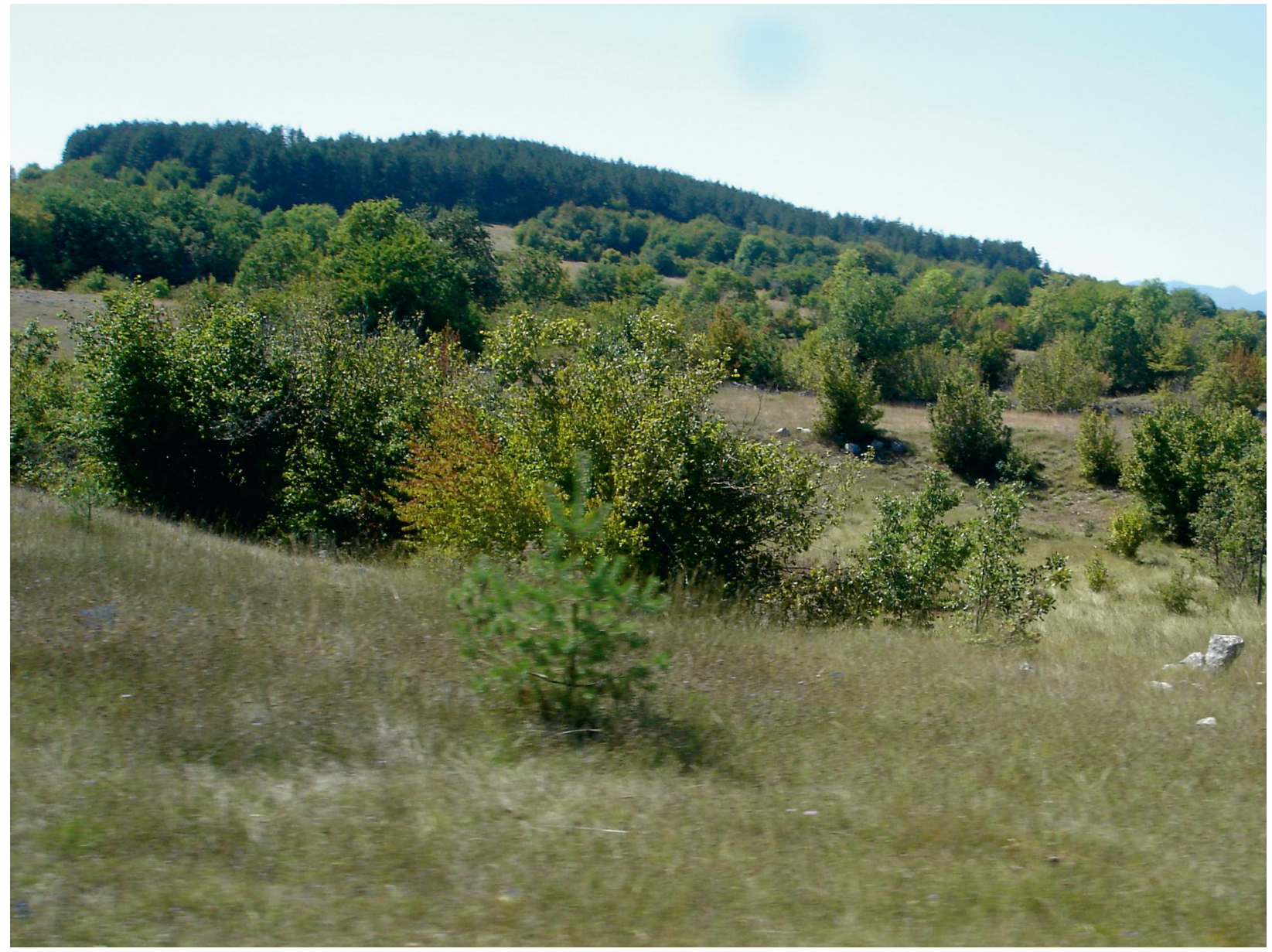

Fig. 10 Succession vegetation, second phase development subtype - grassland which has turned into scrub/vegetation succession through vegetation succession, photo by M. Hamzić (6 September 2013).

Slika 10. Razvojni podtip Sukcesija vegetacije druge faze - travnato zemljište vegetacijskom sukcesijom promijenjeno u grmlje/sukcesiju vegetacije (snimila M. Hamzić 6. 9. 2013.).

Lika, data from a period covering 32 years (1980-2012) were used. This is a sufficiently long period to record anthropogenic changes (construction of objects such as highways and associated objects) and to note natural changes in the landscape (for example, a series of three phases of vegetation succession). The results of the research showed that in the development of the landscape in Central Lika, stagnation was the dominant feature in the observation period. The landscape development type Stagnation covers most of Central Lika $-89.46 \%$. Another relatively significant process is vegetation succession, which accounts for $5.55 \%$ of the area. Less significant processes are agrarisation, construction and vegetation degradation, which account for very small proportions of the landscape development types (Agrarisation, 2.58\%; Vegetation degradation, 1.31\%; Construction, 0.63\%). As construction and agrarisation processes indicate the intensified use of land, while vegetation succession and degradation indicate abandonment or extensification, it can be concluded that in the observation period (19802012) extensification (6.86\%) was more present than intensification (3.21\%).

These results of research into landscape changes are in accordance with negative socio-geographic indicators and processes in Central Lika (a reduction in the total number of inhabitants, their ageing, deagrarisation and deruralisation). If these negative socio-geographic processes continue, it is to be expected that more land in Central Lika will be abandoned and extensification will increase.

Due to differences in approaches, the use of data, methodological research and period analysed, the results of research conducted in Croatia are not entirely comparable. However, by comparing the results of research in compatible periods, similarities and differences in the processes observed can be

KiG No. 35, Vol. 20, 2021, https://doi.org/10.32909/kg.20.35.1 - ـ 
Tablica 1. Površina i udjeli razvojnih tipova i podtipova krajolika Srednje Like za razdoblje 1980-2012 te površine pripadajućih tipova krajolika iz kojih su se razvili.

Table 1 Surface areas and proportions of landscape development types and subtypes in Central Lika, 1980-2012, and surface areas of associated landscape types from which they developed.

Development Types/ Development subtypes/

landscape development types (1980-2012)/

Razvojni tipovi/ Razvojni podtipovi/

razvoj tipova krajolika (1980-2012)



Construction/ Izgradnja

Scrub/forest succession - Built-up land/ Grmlje/sukcesija šume - Izgrađeno zemljište Agricultural land - Built-up land/ Poljoprivredno zemljište - Izgrađeno zemljište Forest land - Built-up land/ Šumsko zemljište - Izgrađeno zemljište Grassland - Built-up land/ Travnato zemljište - Izgrađeno zemljište Agrarianisation/ Agrarizacija

Scrub/forest succession - Agricultural land/ Grmlje/sukcesija šume - Poljoprivredno zemljište Built-up land - Agricultural land/ Izgrađeno zemljište - Poljoprivredno zemljište Forest land - Agricultural land/ Šumsko zemljište - Poljoprivredno zemljište Grassland - Agricultural land/ Travnato zemljište- Poljoprivredno zemljište Vegetation Succession/ Sukcesija vegetacije Vegetation succession, first phase/ Sukcesija vegetacije 1. faze Agricultural land - Grassland / Poljoprivredno zemljište - Travnato zemljište Rocky surfaces - Grassland/ Stjenovite površine - Travnato zemljište Vegetation succession, second phase/ Sukcesija vegetacije 2. faze Rocky surfaces - Scrub/forest succession/ Stjenovite površine - Grmlje/sukcesija šume Agricultural land - Scrub/forest succession/ Poljoprivredno zemljište - Grmlje/sukcesija šume Grassland - Scrub/forest succession/ Travnato zemljište - Grmlje/sukcesija šume Built-up land - Scrub/forest succession/ Izgrađeno zemljište - Grmlje/sukcesija šume Vegetation succession, third phase/ Sukcesija vegetacije 3. faze Rocky surfaces - Forest land/ Stjenovite površine - Šumsko zemljište Scrub/forest succession - Forest land/ Grmlje/sukcesija šume - Šumsko zemljište Grassland - Forest land/ Travnato zemljište - Šumsko zemljište Built-up land - Forest land/ Izgrađeno zemljište - Šumsko zemljište Agricultural land - Forest land/ Poljoprivredno zemljište - Šumsko zemljište Vegetation Degradation/ Degradacija vegetacije

Forest land - Scrub/forest succession/ Šumsko zemljište - Grmlje/sukcesija šume Forest land - Grassland/ Šumsko zemljište - Travnato zemljište

Scrub/forest succession - Grassland/ Grmlje/sukcesija šume - Travnato zemljište Stagnation/ Stagnacija

$$
\begin{gathered}
1,057.9508 / \mathbf{1 0 5 7 , 9 5 0 8} \\
112.0746 / 112,0746 \\
311.5143 / 311,5143 \\
266.5832 / 266,5832 \\
367.7787 / 367,7787
\end{gathered}
$$$$
4,352.3125 / 4352,3125
$$

Scrub/forest succession - Scrub/forest succession/ Grmlje/sukcesija šume - Grmlje/sukcesija šume 19,205.1806/ 19205,1806

Built-up land - Built-up land/ Izgrađeno - Izgrađeno

Agricultural land - Agricultural land/ Poljoprivredno - Poljoprivredno

Forest land - Forest land/ Šumsko zemljište - Šumsko zemljište

Grassland - Grassland/ Travnato zemljište - Travnato zemljište

Water Areas/ Vodene površine

Water areas - Water areas/ Vodene površine - Vodene površine

Water areas - Scrub/forest succession/Vodene površine - Grmlje/sukcesija šume

Water areas - Built-up land/ Vodene površine - Izgrađeno zemljište

Water areas - Agricultural land/ Vodene površine - Poljoprivredno zemljište

Water areas - Forest land/ Vodene površine - Šumsko zemljište

Water areas - Grassland/ Vodene površine - Travnato zemljište

Grassland - Water areas/ Travnato zemljište - Vodene površine

Forest land - Water areas/ Šumsko zemljište - Vodene površine

Agricultural land - Water areas / Poljoprivredno zemljište - Vodene površine

Scrub/forest succession - Water areas/ Grmlje/sukcesija šume - Vodene površine Built-up land - Water areas/ Izgrađeno zemljište - Vodene površine Total/ Ukupno
$1,709.9141 / 1709,9141$

$65.0083 / 65,0083$

$51.6343 / 51,6343$

2,525.7557/2525,7557

9,388.2991/ 9388,2991

2,001.4283/2001,4283

$2,001.4277 / 2001,4277$

$0.0006 / 0,0006$

$5,258.5656 / 5258,5656$

$47.6659 / 47,6659$

$3,265.8296 / 3265,8296$

$1,910.9116 / 1910,9116$

$34.1585 / 34,1585$

2,128.3053/2128,3053

$0.0011 / 0,0011$

$1,654.4556 / 1654,4556$

$346.8202 / 346,8202$

$0.1296 / 0,1296$

$126.8986 / 126,8986$

2,220.0882/ 2220,0882

$1,355.6782 / 1355,6782$

$221.5191 / 221,5191$

$642.8909 / 642,8909$

151,177.1571/ 151177,1571

$89.46 / 89,46$

$1,118.7672 / 1118,7672$

$0.63 / 0,63$

$2.58 / 2,58$

$5.55 / 5,55$

$1.18 / 1,18$

$3.11 / 3,11$

$1.26 / 1,26$

$1.31 / 1,31$

$22,286.8629 / 22286,8629$

91,117.1964/91117,1964

$17,449.1500 / 17449,1500$

$795.8667 / 795,8667$

$686.2167 / 686,2167$

$0.0387 / 0,0387$

$0.0036 / 0,0036$

$0.1555 / 0,1555$

$5.0928 / 5,0928$

$0.1089 / 0,1089$

$26.2555 / 26,2555$

$9.3003 / 9,3003$

$49.4388 / 49,4388$

$19.2516 / 19,2516$

$0.0042 / 0,0042$

$168,991.6743 / 168991,6743 \quad 100.00 / 100,00$ 
noted. Thus, for example, research into environmental changes on the island of Hvar (1975-2011) also confirmed the predominance of the stagnation process and various forms of abandonment processes in the landscape, although the latter were on a greater scale ( $47 \%$, or $48 \%$ of the research area) (Morić-Španić and Fuerst-Bjeliš 2017). Similar findings, with more expressed processes of extensification and vegetation succession, have been shown by research in the interior of Dalmatia (Fuerst-Bjeliš 2018) in studies in Dalmatinska zagora (Fuerst-Bjeliš et al. 2011) and the south slopes of Svilaja mountain (Durbešić 2012, Durbešić and Fuerst-Bjeliš 2016). On the other hand, research into individual areas in continental Croatia has noted more significant processes of intensification of land use. In a thirty-year period from 1981 to 2011 , construction was confirmed on over $7 \%$ of the area of northern Croatia (Jogun et al. 2017), while in a twenty-year period from 1991 to 2011, in Krapina-Zagorje County, $8 \%$ of change in land cover/ land use was found in relation to construction, and as much as $32 \%$ in relation to agrarisation (Cvitanović 2014).

The applied model presented in this paper is also applicable at other spatial levels (for example, regional or national), and for other purposes (for example, recording, monitoring or planning vegetation zones or construction zones, etc.). The data used in this paper (CLC 1980 and CLC 2012) were obtained using methodology harmonised at the European level (CLC methodology), which means they are fully standardised and comparable at the European level.

This model used the spatial analysis method Standard Deviational Ellipse (Directional Distribution), which means that the location of observed objects, that is the landscape development subtypes of Central
Lika, was considered. Additionally, this method, in relation to similar research into landscape changes and land use, allows spatial gradation of established phases of change or processes. In this way, processes of change in the landscape or land use can be spatially connected and correlated with corresponding spatially differentiated social processes in a causal relationship, and this gives added value to the research results.

\section{Sources}

Database: Corine Land Cover 1980, HAOP, Zagreb Database: Corine Land Cover 2012, HAOP, Zagreb

Database: Digital atlas of the Republic of Croatia, State Geodetic Administration (SGA), Zagreb

Database: Central register of spatial units, State Geodetic Administration (SGA), Zagreb

SGA (2012): Topographic map, scale 1:25 000, sheets: Bakovac Kosinjski, 4515-4-3-2, Baške Oštarije, 4515-4-3-4, Bunić, 4516-3-3-1, Gornji Kosinj, 4515-4-4-1, Gospić (Istok), 4515-4-4-4, Gospić (Zapad), 4515-4-4-3, Gračac 4416-1-2-3, Karlobag 4515-43-3, Krasno 4515-4-1-3, Krbava 4516-3-3-4, list Lički Ribnik 44152-2-2, Ličko Lešće, 4515-4-2-3, Lovinac, 4416-1-1-2, Lukovo Šugarje, 4415-2-1-2, Medak, 4516-1-1-1, Ondić, 4416-1-2-1, Otočac, 4515-4-1-4, Perušić, 4515-4-4-2, Rizvanuša, 4515-2-2-1, Sveti Rok, 4416-1-1-4, Štirovača, 4515-4-3-1, Vaganski Vrh, 44161-1-3, Vrhovine, 4515-4-2-4, Velika Paklenica, 4415-2-2-4, Vrebac, 4516-3-3-3

\section{Acknowledgement}

This research was supported by the University of Zagreb Grant for 2020 (no. 20285705) and by company Ericsson Nikola Tesla d.d.

\section{References/ Literatura}

Andlar G, Aničić B, Pereković P, Rechner Dika I, Hrdalo I (2011) Kulturni krajobraz i legislativa - stanje u Hrvatskoj. Društvena istraživanja: časopis za društvena pitanja, vol. 20, no. 3 (113), 813-835. doi: 10.5559/di.20.3.11

Antrop M, (2005) Why landscapes of the past are important for the future. Landscape and Urban Planning, vol. 70, no. 1-2, 21-34. doi: 10.1016/.landurbplan.2003.10.002

Blaće A (2015) Razvoj i suvremena preobrazba krajolika Ravnih kotara. Doktorski rad, Sveučilište u Zagrebu, Prirodoslovnomatematički fakultet, Geografski odsjek, Zagreb

Blaće A (2019) Promjene šumskoga pokrova na području Ravnih kotara u drugoj polovici 19. stoljeća. Hrvatski geografski glasnik, vol. 81, no. 2, 69-88. doi: 10.21861/HGG.2019.81.02.03

Carver S, Comber A, McMorran R, Nutter S (2012) A GIS-model for mapping spatial patterns and distribution of wild land in Scotland. Landscape and urban planning, vol. 104, no. 3-4, 395-409. doi: 10.1016/j.landurbplan.2011.11.016

Cvitanović M (2014) Promjene zemljišnog pokrova i načina korištenja zemljišta u Krapinsko-zagorskoj županiji od 1991. do 2011. Hrvatski geografski glasnik, vol. 76, no. 1, 41-59. doi: 10.21861/HGG.2014.76.01.03

Cvitanović, M (2014a) Promjene zemljišnog pokrova i načina korištenja zemljišta u Krapinsko-zagorskoj županiji od 1978. do 2011. Doktorski rad, Sveučilište u Zagrebu, Prirodoslovno-matematički fakultet, Zagreb 
Sukcesija vegetacije je razvojni tip krajolika na koji se odnosi 5,55\% područja Srednje Like gdje je u promatranom razdoblju promijenjeno zemljište iz drugih zemljišnih pokrova i načina korištenja zemljišta u travnato zemljište, grmlje/sukcesija šume ili šumsko zemljište. S obzirom na položaj, utvrđeno je kako se taj razvojni tip krajolika nalazi na južnom dijelu područja Grada Gospića.

$\mathrm{Na}$ Sukcesiju vegetacije prve faze, kao razvojnog podtipa, odnosi se $1,18 \%$ područja Srednje Like gdje je promijenjeno zemljište iz drugih zemljišnih pokrova i načina korištenja zemljišta u travnato zemljište. Taj se razvojni podtip najvećim dijelom odnosi na promjenu poljoprivrednog zemljišta $u$ travnato zemljište, što je uvjetovano sve manjim bavljenjem poljoprivrednim djelatnostima (tablica 1).

Na području Srednje Like je 3,11 \% zemljišta promijenjeno u grmlje/sukcesiju vegetacije, što je definirano kao razvojni podtip krajolika Sukcesija vegetacije druge faze. Najznačajniji je razvoj u grmlje/sukcesiju šume iz poljoprivrednog zemljišta, odnosno travnatog zemljišta (tablica 1 ).

Na razvojni podtip krajolika Sukcesija vegetacije tréé faze odnosi se 1,26 \% područja Srednje Like koje je promijenjeno $u$ šumsko zemljište. Pri tome, utvrđen je najznačajniji razvoj iz grmlja/sukcesije šume (2. faze), a zatim iz travnatog te poljoprivrednog zemljišta (1. faze).

Korištenjem metode prostorne analize Elipse standardnih devijacija (Distribucija smjerova) detaljnije je analizirana prostorna distribucija triju faza sukcesije vegetacije za razdoblje 1980-2012.

Ustanovljeno je prostorno stupnjevanje utvrđenih faza sukcesije vegetacije (razvojnih podtipova) od središnjeg dijela prema rubnom području istraživanja. Vidljivo je (žuta elipsa na slici 8) kako se razvojni podtip Sukcesija vegetacije prve faze nalazi bliže središnjem dijelu područja istraživanja, odnosno području Grada Gospića, gdje je najmanji odljev stanovništva i gdje je zabilježeno najmanje (i najkasnije) smanjenje poljoprivredne djelatnosti. S druge strane, razvojni podtip Sukcesija vegetacije treće faze nalazi se bliže rubnom dijelu (tamnozelena elipsa na slici 8), gdje je odljev stanovništava značajniji, a promjena načina korištenja zemljišta (poljoprivreda) najranije započela te se zbog dugog vremenskog trajanja sukcesije vegetacije razvilo šumsko zemljište. Razvojni podtip Sukcesija vegetacije druge faze nalazi se između njih (zelena elipsa na slici 8), što ukazuje na prijelazna obilježja.

Razvojni tip krajolika Degradacija vegetacije odnosi se na 1,31 \% područja Srednje Like gdje je u promatranom razdoblju promijenjeno zemljište iz grmlja/sukcesije šume ili šumskog zemljišta u travu ili grmlje/sukcesiju vegetacije. Pri tome je dominantna promjena iz šumskog zemljišta u grmlje/sukcesiju vegetacije. S obzirom na položaj, taj razvojni tip rasprostranjen je na cijelom području istraživanja.

Stagnacija je razvojni tip na koji se odnosi najveći dio $(89,46 \%)$ područja Srednje Like, što proces stagnacije čini dominantnim. Obuhvaća područja gdje nije došlo do promjene i prenamjene. S obzirom na položaj, taj razvojni tip krajolika utvrđen je na cijelom području istraživanja, iako najmanje $u$ središnjem dijelu Grada Gospića. Na razvojni tip krajolika Vodene površine odnosi se 0,47 \% područja Srednje Like koje je $\mathrm{u}$ jednoj od promatranih godina bilo pod vodenom površinom. To se odnosi na vodna tijela, tj. jezera (npr. Kruščica, Štikada, Sv. Rok) te donji dio toka ponornice Like.

\section{Rasprava i zaključne napomene}

S ciljem utvrđivanja razvojnih tipova i podtipova krajolika te prostornog stupnjevanja triju faza sukcesije vegetacije područja Srednje Like, korišteni su podatci za razdoblje od 32 godine (1980-2012), što je dovoljno dug period za evidentiranje antropogenih promjena (izgrađenih objekata, npr. autocesta i popratni objekti), kao i za uočavanje prirodnih promjena $u$ krajoliku (npr. slijed od 1. do 3. faze sukcesije vegetacije).

Rezultati istraživanja su pokazali kako je u razvoju krajolika Srednje Like u promatranom razdoblju dominantna stagnacija. Tako razvojni tip krajolika Stagnacija obuhvaća najveći dio područja Srednje Like - 89,46 \%. Relativno je značajan proces vegetacijske sukcesije te se na taj razvojni tip krajolika odnosi ukupno 5,55 \% područja. Manje su značajni procesi agrarizacije, izgradnje i degradacije vegetacije koji imaju i vrlo male udjele $u$ razvojnim tipovima krajolika (Agrarizacija 2,58 \%; Degradacija vegetacije 1,31 \%; Izgradnja 0,63\%). Kako su izgradnja i agrarizacija procesi koji označavaju intenzifikaciju korištenja zemljišta, a sukcesija vegetacije i degradacija procesi koji ukazuju na zapuštanje, odnosno ekstenzifikaciju, tada se može zaključiti kako je u promatranom razdoblju (1980-2012) zastupljenija ekstenzifikacija (6,86 \%) od intenzifikacije korištenja zemljišta (3,21\%).

Navedeni rezultati istraživanja promjena krajolika sukladni su negativnim društveno-geografskim pokazateljima i procesima u Srednjoj Lici (smanjenje ukupnog broja i starenje stanovništva, deagrarizacija, deruralizacija). Ukoliko se nastave prisutni negativni društveno-geografski procesi, za očekivati je i 
Cvitanović M, Fuerst-Bjeliš B (2018) Marginalization Between Border and Metropolis: Drivers of Socio-Spatial Change in Postsocialist Croatia. In: Pelc S, Koderman M (eds) Nature, Tourism and Ethnicity as Drivers of (De)Marginalization, Insights to Marginality from Perspective of Sustainability and Development, Springer International Publishing AG, Cham, Switzerland, 313-327. doi: 10.1007/978-3-319-59002-8_21

Durbešić, A (2012) Promjene pejzaža južne padine Svilaje - GIS pristup. Doktorski rad, Sveučilište u Zagrebu, Prirodoslovnomatematički fakultet, Zagreb.

Durbešić A, Fuerst-Bjeliš B (2016) Tipovi i trendovi promjene pejzaža planine Svilaje - Ogorje. Ekonomska i ekohistorija: časopis za gospodarsku povijest i povijest okoliša, vol. 12, no. 12, 208-220

Esbah H (2009) Analyzing Landscape Change Through Lanscape Structure Indices: Case of the City Aydin, Turkey. Journal of Applied Sciences, vol. 9, no. 15, 2744-2752. doi: 10.3923/jas.2009.2744.2752

ESRI (2020) How Directional Distribution: Standard Deviational Ellipse (Spatial Statistics) works. In: http://resources.esri.com/help/9.3/arcgisdesktop/com/gp_toolref/spatial_statistics_tools/how_directional_distribution_colon_st andard_deviational_ellipse_spatial_statistics_works.htm. Accessed 1 October 2020

Fuerst-Bjeliš B, Lozić S, Perica D (2000) Man and the environment in the central Velebit area - Baške Oštarije and sorrundings. Acta geographica Croatica, vol. 35, no. 1, 111-132

Fuerst-Bjeliš B (2003) Reading the Venetian Cadastral Record: An Evidence for the Environment, Population and Cultural Landscape of the 18th Century Dalmatia. Hrvatski geografski glasnik, vol. 65, no. 1, 47-62

Fuerst-Bjeliš B, Lozić S, Cvitanović M, Durbešić A (2011) Promjene okoliša središnjeg dijela Dalmatinske zagore od 18. stoljeća. In: Matas M, Faričić J (eds) Proceedings: Zagora između stočarsko-ratarske tradicije te procesa litoralizacije i globalizacije: zbornik radova, Zadar - Dugopolje, 19-21 October 2010,117-129

Fuerst-Bjeliš B (2018) Deforestacija i reforestacija u hrvatskome dinarskom kršu: Odnosi i implikacije. Ekonomska i ekohistorija, vol. 14, no.1, 136-144

Gabrovec M, Kumer, P (2019) Land-use in Slovenia from the Franciscean Cadaster until today. Acta geographica Slovenica, vol. 5 , no. 1, 63-81. doi: 10.3986/AGS.4892

Geršič M, Gabrovec M, Zwitter Ž (2018) Primerjava kulturne pokrajine Hraških listnekov in tamkajšnjega kmetovanja v prvi polovici 19. stoletja in danes//Comparing the cultural landscape of Hraški listneki and farming there in the first half of the nineteenth century and today. Geografski vestnik, vol. 90, no. 1, 61-84. doi: 10.3986/GV90104

Goodchild M F (1993) The state of GIS for environmental problem-solving. In: Goodchild M F, Parks B 0, Steyaert L T (eds) Environmental modelling with GIS, Oxford University Press, New York, 8-15

Hall R, Tewdwr-Jones M (2011) Urban and Regional Planning. Routledge, London

Hrdalo I, Aničić B, Pereković P, Rechner I, Andlar G (2008) The typology of the agricultural landscape of dubrovačko primorje as a basis for directing development. Journal of Central European Agriculture, vol. 9, no. 1, 77-94

Isidoro J M G P, Fernandez H M N P V, Martins F M G, De Lima, J L M P (2012) GIS-Based Models as Tools for Environmental Issues: Applications in the South of Portugal. In: Bateira C (eds) Cartography - A Tool for Spatial Analysis, InTech0pen. doi: 10.5772/48218

Jogun T, Pavlek K, Belić T, Buhin S, Malešić N (2017) Promjene zemljišnog pokrova u sjevernoj Hrvatskoj od 1981. do 2011. godine. Hrvatski geografski glasnik, vol. 79, no. 1, 33-59. doi: 10.21861/HGG.2017.79.01.02

Jogun T, Lukić A, Gašparović M (2019) Simulation model of land cover changes in a post-socijalist peripheral rural area: PožegaSlavonia County, Croatia. Hrvatski geografski glasnik, vol. 81, no. 1, 31-59. doi: 10.21861/HGG.2019.81.01.02

Lončar J, Cvitanović M (2012) (Post)socijalizam i okoliš: promjena kulturnog krajobraza Pridravske nizine Osijeka u posljednjih pedeset godina. Sociologija i prostor, vol. 50, no. 3, 327-343. doi: 10.5673/sip.50.3.3

Morić-Španić A, Fuerst-Bjeliš B (2017) The GIS-model for the revitalisation of traditional island cultures: the island of Hvar, Croatia. In: Pina H, Martin F (eds) The Overarching Issues of the European Space: Society, Economy and Heritage in a Scenario Towards Greater Territorial Cohesion, Faculdade de Letras da Universidade do Porto, Porto, 374 - 392

Mücher C A, Klijn J A, Wascher D M, Schaminée J H J (2010) A new European Landscape Classification (LANMAP): A transparent, flexible and user-oriented methodology to distinguish landscapes. Ecological Indicators, vol. 10, no. 1, 87-103

Pejnović D (1985) Srednja Lika: socijalnogeografska transformacija. Centar za kulturu - Muzej Like, Gospić

Pelcer Z, Martinović J (2003) Odnos tla i šumske zajednice. In: Bogunović M (eds) Tla Gorske Hrvatske, Ministarstvo zaštite okoliša i prostornog uređenja, Ministarstvo znanosti i tehnologije, Zagreb and 0sijek, 56-68

Perry, G L W, Sparrow A D, Owens I F (1999) A GIS-supported model for the simulation of the spatial structure of wildland fire, Cass Basin, New Zealand. Journal of Applied Ecology, vol. 36, no. 4, 502-518. doi: 10.1046/j.1365-2664.1999.00416.x

Van Eetvelde V, Antrop M (2009) Indicators for assessing changing landscape character of cultural landscapes in Flanders (Belgium). Land Use Policy, vol. 26, no. 4, 901-910

Vogiatzakis I N (2003) GIS-based Modelling and Ecology: A Review of Tools and Methods. Geographical paper, no. 170 , p. 34. Available via Researchgate. http://www.researchgate.net/publication/228685580_GISbased_modelling_and_ecology_A_review_of_tools_and_methods. Accessed 1 October 2020

Waters N M (2002) Modeling the Environmnent with GIS: A Historical Perspective. In: Clarke K C, Parks B 0, Crane M P (eds) Geographic Information Systems and Environmental Modeling, Prentice-Hall, Upper Saddle River, New Jersey, 1-35

Wong D W S (1999) Several fundamentals in implementing spatial statistics in GIS: using centrographic measures as examples. Geographic Information Sciences, vol. 6, no. 2, 163-174. doi:10.1080/10824009909480525 
nastavak zapuštanja, odnosno ekstenzifikacije korištenja zemljišta na području Srednje Like.

Zbog različitosti u pristupima, korištenim podatcima, metodologijama istraživanja i analiziranim razdobljima, dobiveni rezultati provedenih istraživanja za prostor Hrvatske nisu u potpunosti usporedivi. Međutim, usporedbom rezultata istraživanja podudarnih razdoblja, moguće je uočiti sličnosti, odnosno različitosti opaženih procesa. Tako su, primjerice, istraživanja promjena okoliša otoka Hvara (1975-2011), također utvrdila prevladavanje procesa stagnacije i različitih oblika procesa zapuštanja krajolika, iako potonjeg u mnogo većoj mjeri ( $47 \%$, odnosno $48 \%$ područja istraživanja) (Morić-Španić i Fuerst-Bjeliš 2017). Slične nalaze s izraženijim procesima ekstenzifikacije i vegetacijske sukcesije pokazala su i istraživanja unutrašnjeg dalmatinskog područja (Fuerst-Bjeliš 2018) na studijama slučaja Dalmatinske zagore (Fuerst-Bjeliš i dr. 2011) i južnih padina Svilaje (Durbešić 2012, Durbešić i Fuerst-Bjeliš 2016). S druge strane, istraživanja pojedinih područja kontinentske Hrvatske zabilježila su nešto značajnije procese intenzivnijeg korištenja zemljišta. Tako je u tridesetogodišnjem razdoblju (19812011) izgradnja utvrđena za više od 7 \% područja sjeverne Hrvatske (Jogun i dr. 2017), dok se u dvadesetogodišnjem razdoblju (1991-2011) u Krapinsko-zagorskoj županiji 8 \% promjena zemljišnog pokrova i načina korištenja zemljišta odnosi na izgradnju, a čak 32 \% na agrarizaciju (Cvitanović 2014).

Primijenjeni model, prikazan $u$ ovom radu je primjenjiv i na drugim prostornim razinama (npr. regionalnim, državnim) te u različite svrhe (npr. evidentiranja, praćenja ili planiranja vegetacijskih zona, odnosno zona izgrađenosti i sl.). Naime, podatci korišteni u ovom radu (CLC 1980 i CLC 2012) dobiveni su korištenjem metodologije usklađene na europskoj razini (CLC metodologija), što ih čini potpuno standardiziranima i usporedivima na razini Europe.
U modelu je korištena metoda prostorne analize Elipse standardnih devijacija (Distribucija smjerova) pri kojoj se promatra prostorni razmještaj promatranih objekata, odnosno razvojnih podtipova krajolika Srednje Like. Ta metoda, dodatno, u odnosu na slična istraživanja promjena krajolika i načina korištenja zemljišta, omogućuje prostorno stupnjevanje utvrđenih faza promjene, odnosno procesa. Na taj se način procesi promjena krajolika i načina korištenja zemljišta mogu prostorno povezati i korelirati s odgovarajućim prostorno diferenciranim društvenim procesima u kauzalnom odnosu, što rezultatima istaživanja daje dodatnu vrijednost.

\section{Izvori podataka}

Baza podataka: Corine Land Cover 1980, HAOP, Zagreb Baza podataka: Corine Land Cover 2012, HAOP, Zagreb

Baza podataka: Digitalni atlas Republike Hrvatske, Državna geodetska uprava (DGU), Zagreb

Baza podataka: Središnji registar prostornih jedinica, DGU, Zagreb

DGU (2012): Topografska karta u mjerilu 1:25 000, listovi: Bakovac Kosinjski, 4515-4-3-2, Baške Oštarije, 4515-4-34, Bunić, 4516-3-3-1, Gornji Kosinj, 4515-4-4-1, Gospić (Istok), 4515-4-4-4, Gospić (Zapad), 4515-4-4-3, Gračac 4416-1-2-3, Karlobag 4515-4-3-3, Krasno 4515-4-1-3, Krbava 4516-3-3-4, list Lički Ribnik 4415-2-2-2, Ličko Lešće, 4515-4-2-3, Lovinac, 4416-11-2, Lukovo Šugarje, 4415-2-1-2, Medak, 4516-1-1-1, Ondić, 44161-2-1, Otočac, 4515-4-1-4, Perušić, 4515-4-4-2, Rizvanuša, 45152-2-1, Sveti Rok, 4416-1-1-4, Štirovača, 4515-4-3-1, Vaganski Vrh, 4416-1-1-3, Vrhovine, 4515-4-2-4, Velika Paklenica, 4415-22-4, Vrebac, 4516-3-3-3

\section{Zahvala}

Objava rada potpomognuta je Potporom Sveučilišta u Zagrebu za 2020. godinu (broj: 20285705) i potporom firme Ericsson Nikola Tesla d.d. 